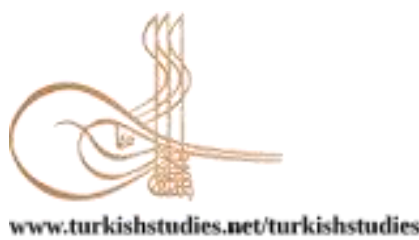

Turkish Studies

\title{
Mültecilerin Eğitime Erişmeleri Sürecinde Yaşadıkları Sorunlar ve Sosyal İçerilme Beklentileri"
}

\author{
Problems the Refugees Face During Access to Education and Their Social Inclusion Expectations
}

\author{
Hakan Topaloğlu**- Murat Özdemir***
}

\begin{abstract}
Aim of this research is examine the problems about accessible education of the refugees being forced to leave their country due to the wars and conflicts and took refuge in Turkey and their social inclusion expectations. In the research, one of the qualitative research methods, phenomenological model was used with the aim of examine the opinions of the participants. Research datas are attained via semi structured interview form. Research data was gathered between January 2020 and February 2020. In this context, in-depth interviews were made with 6 Iraqi, 5 Syrian and 3 Afghanistan refugees who are parents and living in Samsun. Participants are determined by purposeful and criterion sampling methods. 4 of the participants are men and 10 are women. The data obtained in the research were analyzed by content analysis. Research findings are structured as themes, sub-themes and categories. As a result of the research; reason of the refugees took refuge in Turkey, wars and conflicts and other reasons welded two sub-theme or title, depending on security, proximity, economy, Turkey's being Islamic country and consisting of Turkmen categories were obtained. Language, exclusion-snoring, violence, positive teacher behaviors and close culture and religion categories were reached in the sub-theme of positive and negative experiences depending on the theme of access to education. Regarding the sub-themes of exclusion and acceptance depending on the main theme of refugees' adaptation to society and their acceptance experiences, the categories of contempt, violence, non-employment and low salary, non-greet and fear, good employers and helpful neighbors were obtained. Depending on the social inclusion expectations theme of the refugees, the sub-themes of the expectations from the state and society have been reached. Depending on the sub-theme of expectations from the state, citizenship, insured job, health, education and money aid categories were obtained. Depending on the sub-theme of the expectations from the society, neighborhood, respect and non-contempt categories were reached.
\end{abstract}

Structured Abstract: Throughout the history, Turkey has been a country of attraction for the participants of immigration movement due to its geographical location and due to having better life conditions, economical structure, areas of freedom and most importantly, being a safer country in comparison with the neighboring

\footnotetext{
* $\mathrm{Bu}$ çalışma birinci yazarın Mültecilerin sosyal içerilmeleri bağlamında eğitime erişmelerinde yaşanan problemler ve çözüm önerileri başlıklı doktora tezinden türetilmiştir.

${ }^{* *}$ Öğr. Gör., Ondokuz Mayıs Üniversitesi, Terme Meslek Yüksekokulu, Pazarlama ve Reklamcılık Bölümü Lect. Ondokuz Mayls University, Terme Vocational School, Department of Marketing and Advertising ORCID 0000-0003-0370-5826

hakant@omu.edu.tr

*** Prof. Dr., Hacettepe Üniversitesi, Eğitim Fakültesi, Eğitim Bilimleri Bölümü

Prof. Dr. Hacettepe University, Faculty of Education, Educational Sciences

ORCID 0000-0002-1166-6831

mrtozdem@hacettepe.edu.tr

Cite as/ Atıf: Topaloğlu, H., Özdemir, M. (2020). Mültecilerin eğitime erişmeleri sürecinde yaşadıkları sorunlar ve sosyal içerilme beklentileri. Turkish Studies, 15(3), 2033-2059. https://dx.doi.org/10.29228/TurkishStudies.42697

Received/Geliş: 29 March/Mart 2020

Accepted/Kabul: 20 June/Haziran 2020

Copyright $\odot$ MDE, Turkey
} 
countries. This situation continues today as well. So much so that; nearly four million people left their countries and took refuge in Turkey due to the terror and chaos that started in Iraq first and spread to Syria afterwards (Deniz, 2014). Turkey has opened its doors to the flow of migrants that started in April 2011 and continued increasingly up until today but also started to face significant issues.

It is known that the term social inclusion first started to be used in 90's. Even though the usage of the term social inclusion occurred in 1990's, social inclusion essentially has a significant place in the human history. The mostly emphasized terms in Judaism, Christianism and Islam have been brotherhood, cooperation, charity and solidarity terms. Furthermore, philosophically, protection of human dignity has been recognized as a universal principle by the philosophers and it has been emphasized that people are equal and they should be treated in an honorable way. Universal theory of human rights was also built on terms like sense of responsibility, solidarity and human dignity.

Social inclusion is the recognition that all children, adults and all the individuals are valuable and honorable members of the society with all their differences. At the same time, with removing the barriers and risks put before all the fractions that are excluded like immigrants mainly, social inclusion defends a proactive initiative for the social welfare of these fractions as well. In addition to recognition of good relations and common longings particularly amongst the families with children, social inclusion is also an approach that calls for the approval of diversity. Social inclusion is not only removing the boundaries or barriers, but also removing the physical, social and economic distances that separate humans from each other (Donnelly and Coakley, 2002).

Social inclusion is a theory about how society can become integrated and be in harmony. According to this theory, if everyone participates in the society completely, probability of alienation from the society will be lower and people will respect the social rules and laws. Social inclusion induces social cohesion or an older term, solidarity. Therefore, the result that the social inclusion policies desire to attain is not only justice for individuals but also a steady social order (Collins, 2003).

It is stated that in general, social inclusion has five different critical dimensions (Donnelly and Coakley, 2002). First one is valued recognition which means sensitivity to cultural and sexual differences of all individuals and groups while the second one is human development which refers to nurturing the skills of the groups that are included for them to be worthwhile to themselves and to the others, the third one is involvement and engagement which means being involved with the decisions affecting the society, fourth one is proximity which means reducing social distances between people and the last one is material well being which means providing material resources that will allow children and parents to participate fully in community life.

\section{Purpose}

Purpose of this study is to reveal views of the parents with regard to the issues they face during the access of the refugees to education and their social inclusion expectations. For this purpose, answers to the questions mentioned below were searched:

What are the reasons of the refugees to immigrate to Turkey?

What are the experiences of the refugees with regard to education?

What are the social harmony and recognition experiences of the refugees?

What are the expectations of the refugees from State of the Republic of Turkey and its community in order to feel the sense of belonging to Turkey?

\section{Methods}

This study is structured with phenomenological model which is one of the qualitative research methods. Phenomenological model was chosen in this study as it is aimed to reveal the difficulties during the access to education of the refugees who have taken refuge in Turkey due to the compulsory reasons they had in the countries they used to live and to reveal their social inclusion expectations in consideration of the experiences they have in Turkey. Study group of this research is the parents of the refugee students. In order to ensure the participation of the individuals who have the most beneficial knowledge and experience that will serve the purpose of the research of this study, one of the purposive sampling methods, maximum variation 
sampling method was chosen. The purpose of ensuring maximum variation is to reveal the commonalities and differences between the phenomena that show varieties (Yıldırım ve Şimşek, p. 136). In the study, nationality difference formed the basis of the variation. In the same time, criterion sampling technique was also used since the participants were determined by the researcher in line with the predetermined criteria. Criteria of this research are that the refugee participants should have come to Turkey at least one year ago and at least one of their children should be receiving education in a public school. In the study, 6 Iraqi, 5 Syrian and 3 Afghan were interviewed. To obtain the research data, semi-structured interview form that was developed by the researcher and that is used in the qualitative research methods was used. The data obtained in this study were analyzed with the content analysis method. For the analysis of the research data, firstly all the texts were put in writing, they were read quickly and notes were taken. Afterwards, codes were developed from the parts that were related, similar words, sentences and wordings. Later, categories were formed from the significant data that were suitable for the research. Related codes and categories were determined and then, writing period started. Validity and reliability of the qualitative studies are different from the validity and reliability of the quantitative studies (Yıldırım ve Şimşek, 2013, p. 289). It can be thought that instead of validity and reliability terms, assessments that would be made within the framework of the term trustability forms integrity in the qualitative researches. In this direction, the research was based on the assessments of Miles and Huberman with regard to validity and reliability (2015, pp. 277-290). These are; believability, reliability, triangulation, attestability and transmissibility.

\section{Findings}

Participants of the study stated different experiences with regard to the immigration periods and reasons of the refugee parents from different countries, different nationalities and different sects. These statements were separated into two subthemes as reasons based on war and reasons based on other grounds. Refugee student parents who were the participants of the research stated that they left their countries primarily due to safety issues. They stated that particularly having daughter was difficult in war times as the terror groups tried to capture the girls. The participants stated that they have lost their close relatives due to the war in their countries, they could face bombings anywhere at any time and it did not have meaning to live without safety of life. A part of the participants who have stated that they lived without food and water under the war and oppression and had no economic income possibility also stated that they have immigrated to Turkey because it was close to them. Other reasons of the participants to immigrate to Turkey are that the Turkey is a Muslim country, that they are Turkmen and especially that the girls have the opportunity for education in Turkey.

When the statements of the refugee parents regarding the education period are analyzed, it can be seen that the most distinct coding is in language category. It can be seen that the refugees who have constantly increased particularly as of 2011 in which conflicts and civil wars started solve the language issue, albeit partially, as their duration of stay in Turkey extend. When the codes of the parents regarding education are analyzed, it was seen that refugee parents have faced negative effects like exclusion, ill-treatment or being subject to violence.

When experiences of the refugees regarding social harmony and being accepted were assessed, it was seen that mostly emphasized phenomena was facing acts of contempt excessively. Refugee parents also stated that they were exposed to violence, they were not employed by the employers or they were underpaid when they were employed. Furthermore, they stated that their neighbors did not greet them and they lived with fear and anxiety.

When the research data are analyzed, social inclusion expectations of the refugee parents can be gathered in two subthemes as expectations from the state and expectations from the society. Expectations of the refugee parents from the state are expectations like becoming a Turkish citizen, working at a job with security, accessing free education and health care and receiving cash benefits.

\section{Discussion, Conclusion, Suggestions}

When the first theme of the research, "findings regarding the reasons of refugees to immigrate to Turkey", is assessed, it is seen that the basic reason of the refugee parents to immigrate is wars and conflicts. Howard (2017) also stated that for centuries, wars have been the main reason and mostly the driving force for the mass migrations. Safety, proximity and economy categories have arisen as attached to this theme as well. When this assessment and the immigrants are considered, the root cause of the refugees to leave their countries is wars and conflicts while root cause of immigrating Turkey is the fact that they are all Muslims. People 
interviewed in this study were all Muslims as well. This data coincides with the study of Doğanay (1996) named "Türkiye'ye Göçmen Olarak Gelenlerin Yerleşimi (Location of People Who Migrate to Turkey)".

One of the findings obtained as a result of the research is in regards with the "experiences the refugee parents have regarding access to education". Refugee parents emphasized that the most significant issue they experienced was "language". Omidvar and Richmond emphasized in their study that lack of language proficiency has been a significant problem not only in education but also in harmonization and employment. Not learning the language of the country people migrate to is a problem for refugees not only in education but also in all areas of life. Another finding of the research is that refugee students are being excluded by students and some of the teachers. Raabe (2018) has found out that during the education period, refugee students were excluded mostly by their classmates. Kummitta (2015) on the other hand emphasized that contrary to exclusion, in order to ensure social harmony, participation of all students to the education process in which they can improve themselves and their skills should be increased.

Another finding obtained in the research is that refugee students are being exposed to violence. In the research, it was seen that refugee students were exposed to physical or psychological violence. Raabe (2018) has emphasized that recent studies have focused on the bullying and its effects and that bullying in friendships was an indicator of exclusion, avoiding from friendship was also a type of bullying and that it reduced educational success. When findings about the fitting of the refugees into the society and their inclusion are analyzed, it is seen that a part of the research participants have stated that they were exposed to severe violence, they were ill-treated and lived in constant fear. It came to conclusion that refugees generally are not employed (work permit is required) and even when they are employed, they are either underpaid or not paid at all under various pretexts. Refugee parents stated that they were ill-treated by the local community and by their neighbors, they were not greeted and as a result, they lived with fear and anxiety. This finding is supported by Alpman (2018) as well. Alpman has emphasized that refugees being alienated by the local community of the countries they migrate to develop out of local community seeing themselves at a higher position than the refugees.

It is seen that the majority of the refugee parents feel that they are socially, culturally, communally and economically excluded. This finding coincides with the finding of Khan (2015) "that immigrants and refugees are deprived of their political, social and economic rights, that they work in low paying jobs without security, that they live in slums with violence and that they are excluded from the society."

At the last theme of the research, it was reached to two subthemes from the views obtained from the refugees regarding their social inclusion expectations. These are the expectations of the refugees from the state and from the society. Primal expectation of the refugees from the state is to become a Turkish citizen. Kutlu (2019) has found out that public opinion found the citizenship discussions unfavorable, that they thought it would be a risky process to make the refugees citizens and even if they become citizens, they thought that it should be done with a selective mind. It is also seen in the research findings that some of the participants stated that state should act in a selective manner when conferring citizenship. One of the expectations of the refugees is the request for insured jobs, namely working with job securities. Particularly as a result of employing Syrians as unregistered, unsecured and as cheap labor, it was found out that local community became unemployed so, violence towards them increased and as a result, it caused racist attempts to all refugees without discrimination.

A part of the research participant refugee parents requested for state to provide them monetary aid. A part of the participants on the other hand stated that they didn't request money as long as work permit or job is given to them. In addition, it was seen that particularly Afghan refugees stated that Iraqi and Syrian immigrants were rich and therefore, state should provide monetary aid only to them.

According to the findings obtained as a result of the research, expectations of the refugees are to be respected and not to be ill-treated, not to be perceived negatively and people to have good neighboring relations with them. These expectations are everybody's right as an individual and as a human. In the consideration of the data presented above, school managements and neighborhood units should cooperate and plan activities that will eliminate ethnic discrimination. Educators who exhibit discriminatory behaviors should definitely be warned. There should be a quota arrangement in the schools to which refugees will attend and accumulation at some of the schools should be averted. Researchers on the other hand can make comparisons by reviewing the social inclusion activities in other countries. Furthermore, social inclusion study can be made at undergraduate and academicians level. 
Keywords: Education, refugees, social inclusion, social exclusion, adaptation.

Öz: Bu araştırmanın amacı; yaşadıkları ülkelerde yaşanan kargaşa ve savaşlardan dolayı ülkelerini terk etmek zorunda kalarak Türkiye'ye sığınan mültecilerin eğitime erişmeleri sürecinde karşılaştıkları problemler ve aynı zamanda sosyal içerilme beklentilerini açığa çıkarmaktır. Araştırmada katılımcıların görüşlerini açığa çıkarmak amacıyla nitel araştırma yöntemlerinden fenomenolojik desenden yararlanılmıştır. Araştırma verileri yarı yapılandırılmış bir görüşme formu aracılığıyla elde edilmiştir. Araştırma verileri Ocak ve Şubat 2020 tarihleri arasında toplanmıştır. Bu kapsamda Samsun'da yaşayan ve öğrenci velisi olan, amaçlı ve ölçüt örneklem yöntemleriyle belirlenen 6'sı Iraklı, 5'i Suriyeli ve 3'ü Afganistanlı mültecilerle derinlemesine görüşmeler yapılmıştır. Katılımcıların 4'ü erkek, 10’u kadındır. Araştırmada elde edilen veriler, içerik analizi ile çözümlenmiştir. Araştırma bulguları tema, alt tema ve kategoriler olarak yapılandırılmıştır. Araştırma sonucunda; mültecilerin Türkiye'ye göçlerinin nedenleri temasında, savaş ve çatışma kaynaklı ve diğer nedenler başlık iki alt tema ya bağlı olarak güvenlik, yakınlık, ekonomi, Türkiye'nin Müslüman ülke oluşu ve Türkmenlik kategorileri elde edilmiştir. Eğitime erişim sürecine ilişkin deneyimler temasına bağlı, olumlu ve olumsuz deneyimler alt temasında ise dil, dışlanma-horlanma, şiddet, olumlu öğretmen davranışları ve yakın kültür ve din kategorilerine ulaşılmıştır. Mültecilerin topluma uyumu ve kabullenilme deneyimlerine ilişkin ana temaya bağlı olarak dışlanma ve kabullenilme alt temalarına ilişkin ise hor görülme, şiddet, iş vermeme ve düşük maaş, selamlaşmama ve korku, iyi işverenler ve yardımsever komşular kategorileri elde edilmiştir. Mültecilerin sosyal içerilme beklentileri temasına bağlı olarak devletten ve toplumdan beklentileri alt temalarına ulaşılmıştır. Devletten beklentiler alt temasına bağlı olarak, vatandaşlık, sigortalı iş, sağlık, eğitim ve para yardımı kategorileri elde edilmiştir. Toplumdan beklentiler alt temasına bağlı olarak ise komşuluk, saygı ve hor görülmeme kategorilerine ulaşılmıştır.

Anahtar Kelimeler: Eğitim, mülteciler, sosyal içerme, sosyal dışlanma, uyum.

\section{Giriş}

Türkiye tarih boyunca bulunduğu coğrafi konum ve komşu ülkelerle kıyaslandığında daha iyi yaşam koşulları, ekonomik yapısı, özgürlük alanları ve en önemlisi güvenli bir ülke olması dolayısıyla göç hareketlerine katılanlar için bir çekim ülkesi olmuştur. Bu durum bugün de devam etmektedir. Öyle ki; ilk olarak Irak'ta başlayıp daha sonra Suriye'ye yayılan terör ve kaos ortamı nedeniyle yaklaşık dört milyon kişi ülkelerini terk ederek Türkiye'ye sığınmıştır (Deniz, 2014: 193). 2011 yılının Nisan ayında başlayıp bugüne kadar sayıları artarak devam eden göçmen akınına Türkiye kapılarını açmış fakat ciddi sorunlarla da yüzleşmeye başlamıştır. Bu sorunlarla baş edebilmek için öncelikli olarak yasal düzenlemeler yapılmıştır. Bilindiği gibi Türkiye, 1951 yılında imzalanan Mültecilerin Hukuki Statüsüne İlişkin Cenevre sözleşmesini ve 1967 y1lında imzalanan Mültecilerin Hukuki Statüsüne İlişkin Protokolü coğrafi çekince şartıyla kabul etmiş ve imzalamıştır. Buradaki coğrafi çekince sadece Avrupa ülkelerinden ve 1951 yılından önce cereyan eden olaylar sebebiyle Türkiye'ye sığınanları mülteci kabul edeceğine ilişkindir. Daha sonra 1994 yılında Türkiye 'ye İltica Eden veya Başka Bir Ülkeye Iltica Etmek Üzere Türkiye'den İkamet İni Talep Eden Münferit Yabancılar ile Topluca Sığınma Amacıyla Sınırlarımıza Gelen Yabancılara ve Olabilecek Nüfus Hareketlerine Uygulanacak Usul ve Esaslar Hakkında Yönetmelik (Resmi Gazete, 1994) düzenlenerek Türkiye'ye iltica etmek isteyen yabancıların hukukuna ilişkin bir çerçeve çizilerek yetkili merciler belirlenmiştir. 2003 yılında sığınmacı haklarının korunmasında önemli rol oynayan geri göndermeme ilkesi kabul edilerek 1rk1, dini, aidiyeti, uyruğu veya politik görüşü nedeniyle temel hak ve özgürlükleri tehlike altında olan kişilerin geldikleri ülkelere geri gönderilemeyeceği kabul edilmiştir (Güner, 2016: 215). 2013 yılında ise 6458 sayılı Yabancılar ve Uluslararası Koruma Kanunu kabul edilerek İçişleri Bakanlığı'na bağlı olarak Göç İdaresi Genel Müdürlüğü kurulmuştur. Yasa, 2014 yılında yürürlüğe girmiş ve aynı kanuna tabi olarak Geçici koruma yönetmeliği yayınlanmıştır. 6458 sayılı kanun ve bağlı olarak yürürlüğe giren geçici koruma yönetmeliği uzun zamandır iç hukukunda genel bir düzenleme olmayan Türkiye'deki mülteciler için öneli bir düzenlemedir (Bozbeyoğlu, 2015: 71). Bu kanuna göre; mülteci, şartlı mülteci, ikincil koruma ve 
geçici koruma olmak üzere dört farklı uluslararası koruma şekli düzenlenmiştir. Bu kavramları kısaca özetlemek gerekirse; Avrupa ülkelerinden Türkiye'ye sığınma başvurusunda bulunanları mülteci, Avrupa ülkeleri dışında meydana gelen olaylardan dolayı üçüncü bir ülkeye gitmek amaciyla Türkiye'ye sığınma başvurusunda bulunanlara şartlı mülteci, mülteci veya şartlı mülteci statüsünde değerlendirilmeyen fakat ülkesine geri gönderildiğinde öldürülme veya insanlık dışı muameleye maruz kalabilecek kişilere ikincil koruma, ülkesinden ayrilmak zorunda kalan ve kitlesel olarak sınırlarımızı geçen yabancılara ise geçici koruma statüsü verilmektedir. Türkiye'de sayıları üç milyon yedi yüz bine yaklaşan Suriyelilerin statüsü geçici koruma statüsüdür.

Türkiye'ye yukarıdaki statülerden herhangi biriyle gelen yabancılar ile ilgili yapılan araştırmalar gün geçtikçe artmaktadır. Yapılan çalışmaların büyük bir çoğunluğunda gelen göçmen/sığınmac1/ikincil koruma ve geçici koruma kapsamındaki yabanc1ların tümünün mülteci olarak ifade edildiği görülmektedir (Akkaya, 2013; Akpınar, 2017; Beltekin, 2016; Deniz, Hülür ve Ekinci, 2016; Erdem, 2017; Erdoğan, 2017; Topçu, Türk ve Kantos, 2018; Saklan, 2018; Uzun, 2015; Yavuz ve Mızrak, 2016). Bu araştırmada da mülteci olarak tanımlanmışlardır.

Türkiye'de Aralık 2019 tarihi itibariyle 3.680.000 Suriyeli, 170.000 Afganistan uyruklu ve 142.000 Iraklı olmak üzere yaklaşık dört milyon mülteci yaşamaktadır (UNCHR, 2019). Türkiye'de eğitim çağındaki yabancı öğrenci sayısı ise 1.234 .439 'dur. Bu öğrencilerin $738.046(\% 59,30)$ sinin eğitime erişimi sağlanmıştır. Mülteci öğrencilerin 648.592'si Suriyeli, 58.811'i Iraklı ve 30.637'si ise Afganistan uyrukludur. Türkiye'deki mültecilerin büyük çoğunluğunu oluşturan Suriyelilerin eğitim çağ nüfusu ise 1.047.536'dır (Hayat Boyu Öğrenme, 2019). Bu durumda öğrenim çağındaki öğrencilerin yaklaşık \% 40'ının eğitime erişimi sağlanamamıştır. Bu durum mültecilerin uyumu noktasında dikkate alınması gerekli bir veridir. Mevcut araştırmanın yapıldığ 1 Samsun ilinde de çoğunluğu Iraklı olmak üzere yaklaşık kırk bin mülteci bulunmaktadır. Mülteci öğrenci sayısı ise 6500 civarındadır (MEM, 2020).

Türkiye'ye gelen faklı milliyetlerden mültecilerin sayısının artmaya başladığı 2014 yılından itibaren ülkedeki mültecilerin eğitimi ve eğitime erişimde yaşanan sorunlara ilişkin çok sayılabilecek çalışma yapıldığı görülmektedir. Çalışmaların özellikle sayıları diğer milliyetlerden daha fazla olan Suriyelilerle ilgili olduğu da görülmektedir. Yapılan çalışmaların odağında ise daha çok öğretmen, idareci ve öğrencilerin yaşadıkları sorunlar yer almaktadır. Ancak mültecilerin eğitime erişim sürecinde yaşadıkları sorunları ve sosyal içerilme bağlamında eğitime ilişkin beklentilerine odaklanan çalışmaların alanyazın taramalarında çok sınırlı sayıda olduğu görülmüştür. $\mathrm{Bu}$ çalışmalardan biri Sakız (2016)'ın 18 okul yöneticisi ile yaptığı görüşmelerin sonucunda ulaştığ çıkarımlardır. Sakız, okul yöneticilerinin mülteci öğrencilerin kendi okullarında eğitim görmelerine sıcak yaklaşmadıklarını ve ayrı ortamlarda eğitim almalarını tasvip ettiklerini, mültecilere yönelik toplumdaki olumsuz algının mülteci çocukların eğitiminde olumsuz rol oynadığını ve toplumsal bütünleşmenin gerçekleşebilmesi için tüm kesimlerin psiko-sosyal ve yapısal olarak desteklenmeleri gerektiğini bulgulamıştır. Diğer çalışma, Sumbuloglu, Karabey, Gulle, Saillard ve Koca (2019)'nın YanYana projesidir. Proje, Suriyeli mülteci öğrencilerin topluma kazandırılması amacıyla yapılmış, 20 aylık sürenin sonunda öğrencilerin kendilerini ifade etmelerinde, sosyal becerilerinde ve sınıf içi iletişimlerinde gelişim gözlenmiştir. Bu çalışmanın alanyazına katkı sağlayacağı düşüncesi ile beraber, mültecilerin eğitime erişimde yaşadıkları güçlüklerin giderilmesi yönünde yapılacak uygulamalara katkı sağlayacağı umulmaktadır.

\section{Kavramsal Çerçeve}

Sosyal içerme (social inclusion) kavramının ilk olarak 90'lı yıllarda kullanılmaya başlandığı bilinmektedir. Birleşmiş Milletler Eğitim, Bilim ve Kültür Kurumu (UNESCO)'nun 1994 yılında İspanya'nın Salamanca şehrinde düzenlenen ve 92 ülke, 25 uluslararası kuruluşu temsil eden 300 den fazla kişinin katıldığı "Salamanca Bildirisi" ile sosyal içerme ülkelerin gündemine girmiştir. Bildiri ile sosyal içerme, kapsayıcı eğitim (herkesi kapsayan eğitim) ve herkes için eğitim ilkeleri 
kabul edilmiştir. Bildiri sosyal içerme ilkesini ön planda tutan ve okulların tüm çocuklara hizmet verecek şekilde yani "çeşitlilik" ilkesine uygun yapılandırılmasını hedeflemiştir (UNESCO, 1994).

Sosyal içerme kavramının kullanımı 1990'lı yıllara denk gelse de esasen insanlık tarihinde sosyal içermenin önemli yeri vardır. Musevilik, Hristiyanlık ve İslam dinlerinde en çok vurgulanan kavramlar kardeşlik, yardımlaşma, sadaka ve dayanışma kavramlarıdır. Ayrıca felsefi olarak da antik çağdan itibaren insan onurunun korunması, evrensel ilke olarak tüm felsefeciler tarafindan benimsenmiştir ve insanların eşit oldukları ve onurlu bir şekilde muamele görmeleri gerektiği vurgulanmıştır. Evrensel insan hakları teorisi de sorumluluk bilinci, dayanışma ve insanlık onuru gibi kavramlar üzerine inşa edilmiştir. Bununla beraber özellikle son yüzyılda yaşanan savaşlar, insanların sosyal içerme düşüncesinden uzaklaştığını, totaliter rejimlerin katliamları ve soykırımları ile anılan bir yüzyıl olduğu da bir gerçektir (Bullock, Brestovanský ve Lenčo, 2015: 1-4).

Sosyal içerme, tüm çocukların, yetişkinlerin ve farklılıklarıyla beraber tüm bireylerin toplumun değerli ve saygın bir üyesi olduğunun kabul edilmesidir. Sosyal içerme aynı zamanda daha çok mülteciler gibi dışarıda kalan tüm kesimlerin önüne konulan engellerin ve risklerin kaldırılmasıyla beraber, bu kesimlerin sosyal refahı için proaktif bir girişimi savunur. Sosyal içerme, özellikle çocuklu aileler arasındaki iyi ilişkilerin, ortak özlemlerin tanınmasının yanı sıra, çeşitliliğin onaylanması çağrısında bulunan bir yaklaşımdır. Sosyal içerme sadece sınırları veya engelleri kaldırmak değil aynı zamanda insanları birbirinden ayıran fiziksel, sosyal ve ekonomik mesafeleri de ortadan kaldırmaktır (Donnelly ve Coakley, 2002: 2).

Sosyal içerme, toplumun nasıl bütünleşebileceği ve uyumlu olabileceği teorisidir. Teoriye göre, eğer herkes topluma tamamen katılırsa, topluluktan yabancılaşma olasılığ 1 daha düşük olacak, sosyal kural ve yasalarına da uyacaklardır. Sosyal içerme, sosyal uyumu veya daha eski bir kavram olan dayanışmayı teşvik eder. Bu nedenle, sosyal içerme politikalarının aradığı sonuç, sadece bireyler için adalet değil aynı zamanda istikrarlı bir sosyal düzendir (Collins, 2003: 16-17).

Sosyal içermeyi "sosyal dışlanmanın etkilerinin ortadan kaldırılması için yapılacak çalışmalar" olarak kabul eden sosyal bilimcilerle (Erdoğdu, 2004; Genç ve Çat, 2013; Güler, 2014; Sapancalı, 2005; Şahin, 2009) beraber sosyal dışlanmanın etkilerinin ortadan kaldırılmasından daha ileri bir bakış ve uygulama alanı olarak görenler de (Atkinson, 2004; Beland, 2007; Bullock vd, 2015; Collins, 2003; Das, 2016; Donnelly ve Coakley, 2002; Morrison, 2003; Woolley, 2002) mevcuttur. Doğal olarak sosyal içermenin anlaşılabilmesi için sosyal dışlanma kavramından da bahsetmek daha yararlı olacaktır.

Sosyal dışlanma kavramını ilk olarak 1960'lı yıllarda Fransız Sosyal İşler Bakanı Lenoir, Fransız toplumundaki dışlanmış grupları ifade etmek için kullanmıştır. Lenoir, Fransız toplumunun onda birinin dişlanmadan kaynaklı asosyal insanlar ve sosyal uyumsuzluk içerisindeki insanlardan oluştuğunu tespit etmiştir (Silver, 1994: 536). Sosyal dişlanma, bazı toplum kesimlerinin farklılıklarından kaynaklı olarak toplumsal bütünün ve sermaye birikim sürecinin dışında kalması aynı zamanda toplumsal kaynakların bölüşümünden adil yararlanamamasından dolayı ortaya çıkan, ekonomik, siyasal, kültürel, hukuki ve kişisel boyutları olan bir kavramdır (Sapancalı, 2005: 13). Sosyal dışlanma toplumdaki bazı bireylerin, istihdam, gelir, eğitim ve öğretim, sağlık vb. olanaklardan yani modern devletin vatandaşlık hakkı dediği haklardan mahrum bırakılmasıdır.

Sosyal dışlanma kavramının tanımı üzerinde literatürde bir uzlaşma söz konusu değildir. Çünkü kavram birbirinden farklı (ekonomik, sosyal, politik, kültürel) boyutları içermektedir (Arer, 2020: 34). Fakat sosyal dışlanmanın toplumdaki bütünleşmenin gerçekleşememesinin göstergesi olduğu ifade edilebilir. Castillo (1994: 134) sosyal dışlanmayı; insanların toplumsal yaşamdan uzak kalmasına neden olacak düzeyde hem madden hem de manevi olarak yoksunluk içerisinde yaşamaları ve bireylerin haklarını koruyacak ve onları bu haklarını kullanmaları noktasında destekleyecek kurumlardan ve sosyal desteklerden mahrum bırakan dinamik bir süreç olarak tanımlamıştır. Tania, Julian ve David (1999: 228-229) ise sosyal dışlanmayı; coğrafi olarak aynı 
toplumda yaşayan bir bireyin, kendi kontrolünün dışındaki nedenlerden dolayı, o topluluktaki vatandaşların katıldı̆̆ 1 etkinlik ve faaliyetlere istediği halde katılamaması durumu olarak tanımlamışlardır.

Sosyal içerme ve türevi kelimelerinin kapsadığı anlam artık öyle genişlemiştir ki, artık refah düzeyi ile ilgili pozitif herhangi bir konuda karşımıza çıkabilmektedir (Gelir eşitliği, fakirliğin azalması, eğitim, sağlık, barınma reformları). Fakat açıç̧a görülmektedir ki, insanlar içerme kelimesi ve benzerlerini kullanırken kendilerini fakirliğin azalması veya eşitlik gibi konulardan ziyade daha farklı pozitif gelişmeler çerçevesinde değerlendirmektedirler. Sosyal içerme bir süreci ifade etmektedir. İçerilecek kişi, grup, kesimler için koşullar eşitlendiğinde dahi içerme başarıya ulaşmıştır denilemeyebilir. Örneğin, eşit gelir düzeyine ulaşılması hedeflenmiş ve ulaşılmış ise, sosyal içerme bundan daha fazlası olan "inşa edilmek istenilen toplum tipi" ile ilgilenir. Yani sosyal içermenin ölçülebilir sonuçlarını eşitlemek mümkündür. Özellikle iş imkânları, barınma, eğitimin erişilebilirliği gibi alanlarda. Fakat bir şehirde veya bir şehrin varoşlarında ve ya çevresinde evsiz yaşayan yoksul, göçmen veya farklı ırklardan insanları ele alalım. Bu insanlar için konutlar inşa edilmesi koşulları eşitler ancak sosyal dişlanma bozulmadan devam eder. İyi sonuçlar elde edilse bile, yeni sosyal dışlanma biçimleri oluşturulabilir. Özetle, sosyal içerme sadece eşitliği sağlamakla ilgili değildir; aynı zamanda eşitliğin sağlandığı süreçle de ilgilidir (Das, 2016: 7).

Sosyal içermenin genel olarak beş kritik boyutu olduğu ifade edilmektedir (Donnelly ve Coakley, 2002: 11). Bunlardan birincisi, tüm birey ve grupların kültürel ve cinsiyet farklılıklarına duyarlı1ık anlamına gelen değerleri tanıma, içerilme noktasındaki kesimlerin kendilerine ve başkalarına faydaları olmaları için becerilerini geliştirme anlamına gelen insani gelişim, üçüncüsü, toplumu etkileyen kararlara dahil olma anlamına gelen katılım ve angajman, dördüncüsü, insanlar arasındaki sosyal mesafelerin azaltılması anlamında yakınlık, sonuncusu ise, çocukların ve ebeveynlerin toplum yaşamına dahil olmalarını sağlayacak maddi kaynaklara sahip olmalarının sağlanması anlamına gelen maddi destektir.

$\mathrm{Bu}$ araştırmanın amacı; Mültecilerin eğitime erişmeleri sürecinde yaşadıkları sorunlar ve sosyal içerilme beklentilerine yönelik veli görüşlerini açığa çıkarmaktır. Bu amaçla aşağıdaki sorulara yanıt aranmıştır:

a. Mültecilerin Türkiye'ye göç etmelerinin nedenleri nelerdir?

b. Mültecilerin eğitime erişimle ilgili yaşadıkları deneyimler nelerdir?

c. Mültecilerin toplumsal uyum ve kabullenilme deneyimleri nelerdir?

d. Mültecilerin kendilerini Türkiye'ye ait hissetmeleri için Türkiye Cumhuriyeti

Devletinden ve toplumundan sosyal içerilme beklentileri nelerdir?

\section{Yöntem}

\section{Araştırma deseni}

Bu araştırmada, Türkiye'deki okullarda öğrenim gören çocuğu olan mültecilerin eğitime erişimlerinde yaşadıkları sorunlar ve sosyal içerilme beklentilerini açığa çıkarmak amaçlanmıştır. $\mathrm{Bu}$ amaçla çalışma nitel araştırma yöntemlerinden biri olan fenomenolojik desen ile yapılandırılmıştır. Nitel araştırmalar, derinlemesine ve ayrıntılı bilgi elde etmek için gözlem, görüşme ve doküman analizi gibi nitel veri toplama yöntemlerinin kullanıldığ aynı zamanda sınırlı sayıda kişinin katılımı ile gerçekleştirilen araştırmalardır (Yıldırım, 1999; Patton, 2014; Yıldırım ve Şimşek, 2013, s. 45). Fenomenolojik desen ise, var olan bir sosyal gerçekliği anlamak ve ortaya çıkarmak için araştırmacının kendi önyargılarını bir kenara koyduğu (Shortall, 2003), yaşanan fenomene ilişkin kişilerin deneyimlerini sorgulayarak özüne inmeye çalışan bir araştırma desenidir (Ersoy, 2017: 82; Lester, 1999: 1). Bu araştırmada yaşadıkları ülkelerden zorunlu nedenlerden dolayı ayrılarak Türkiye'ye sığınan mültecilerin, eğitime erişim sürecinde yaşadıkları sorunlar ve sosyal içerilme beklentileri, onların yaşadıkları deneyimler ışığında açığa çıkarılmaya çalışıldığı için fenomenolojik desen tercih edilmiştir. 
Fenomenolojik desen ile kurgulanan çalışmalarda herhangi bir teorik çerçeveye bağlı kalınmadan gerçekçi bir şekilde araştırılan fenomenin tüm özellikleri açık bir şekilde tanımlanmaya çalışılır (Groenewald, 2004). Olgu bilim araştırması denilen fenomenolojik araştırmalarda çalışmanın odaklandığı olguyu bizzat deneyimleyen ve anlatabilen kişiler veri kaynağı olarak değerlendirir (Yıldırım ve Şimşek, 2013: 78).

\section{Çalışma Gurubu}

Samsun Karadeniz bölgesinde en çok mülteci barındıran bir ildir. Aynı zamanda birden fazla milliyete bağlı mültecilerin bulunduğu Samsun'da çoğunluğu Iraklı olmak üzere yaklaşık kırk bin mülteci bulunmaktadır. Samsun'da bu dönemde eğitim kurumlarında öğrenim gören 6638 mülteci öğrenci vardır. Son dört yılda ki öğrenci sayısı ise sürekli artış göstermektedir. Şöyle ki; 2015 yılında 750 civarında olan yabancı öğrenci sayısı bugün 6638'e ulaşmış beraberinde sorunlar da artış göstermiştir (MEM Samsun, 2020). Bu araştırmanın çalışma grubunu mülteci öğrencilerin velileri oluşturmuştur. Bu çalışmada araştırmanın amacına hizmet edecek en yararlı bilgi ve deneyime sahip olan bireylerin çalışma grubuna katılması için amaçlı örneklem yöntemlerinden maksimum çeşitlilik örnekleme tercih edilmiştir. Maksimum çeşitliliğin sağlanmasındaki amaç çeşitlilik gösteren olgular arasındaki ortaklık ve farklılıkların açığa çıkarılmasıdır (Yıldırım ve Şimşek, 2013, s. 136). Çalışmada milliyet farklılıklığı çeşitliliğin temelini oluşturmuştur. Araştırmada aynı zamanda araştırmacı tarafından önceden belirlenen ölçütler doğrultusunda katılımcı belirlendiği için ölçüt örneklem tekniği de kullanılmıştır. Bu araştırmanın ölçütleri, mülteci katılımcıların en az bir y1l önce Türkiye'ye gelmiş olmaları ve en az bir çocuklarının devlet okulunda eğitim görüyor olmasıdır. Bununla beraber görüşmelerin rahat sürdürülebilmesi için katılımcılar orta düzeyin üzerinde Türkçe biliyor olanlardan seçilmiştir. Katılımcılar belirlenirken kolay ulaşılabilir durum örneklemesi de kullanılmış ve katılımcılar mültecilerin en yoğun olduğu okullardan seçilmiştir. Çalışmada 6 Iraklı, 5 Suriyeli ve 3 Afganistanlı ögrenci velisi ile görüşme yapılmıştır. Tablo 1'de araştırmaya katılan mülteci velilerin demografik özellikleri sunulmuştur.

Tablo 1: Katılımcılara İlişkin Demografik Bilgiler

\begin{tabular}{|c|c|c|c|c|c|c|}
\hline $\begin{array}{c}\text { Katılıme1 } \\
\text { Kodu }\end{array}$ & Cinsiyet & Yaş & $\begin{array}{l}\text { Eğitim } \\
\text { durumu }\end{array}$ & Mesleği & $\begin{array}{l}\text { Çocuk sayıs1/ } \\
\text { Okula giden } \\
\text { çocuk sayısı }\end{array}$ & $\begin{array}{c}\text { Gelir } \\
\text { durumu (000 } \\
\text { TL) }\end{array}$ \\
\hline SMV1 & $\mathrm{E}$ & 40 & Lise & İnşaat ustası & $6 / 4$ & $3-4$ \\
\hline SMV2 & $\mathrm{K}$ & 29 & Üniversite & Ev Hanımı & $2 / 1$ & $2-3$ \\
\hline SMV3 & $\mathrm{K}$ & 58 & Üniversite & Öğretmen & $3 / 1$ & $5+$ \\
\hline SMV4 & E & 41 & Ortaokul & Tesisatç1 & $4 / 3$ & Kizılay \\
\hline SMV5 & E & 31 & Lise & Mobilyacı & $3 / 1$ & $2-3$ \\
\hline IMV1 & $\mathrm{K}$ & 38 & Üniversite & Avukat & $4 / 4$ & Kizılay \\
\hline IMV2 & $\mathrm{K}$ & 58 & Lise & Satış danış. & $6 / 3$ & $2-3$ \\
\hline IMV3 & $\mathrm{K}$ & 35 & Üniversite & Doktor & $4 / 4$ & $8+$ \\
\hline IMV4 & K & 41 & Üniversite & Öğretmen & $4 / 4$ & $12+$ \\
\hline IMV5 & $\mathrm{K}$ & 40 & Ortaokul & Terzi & $5 / 3$ & $3-4$ \\
\hline IMV6 & $\mathrm{K}$ & 46 & Ortaokul & Ev hanımı & $6 / 6$ & Kizilay \\
\hline AMV1 & $\mathrm{E}$ & 36 & Doktora & Akademisyen & $3 / 2$ & Kizılay \\
\hline AMV2 & $\mathrm{K}$ & 40 & Yok & Ev hanımı & $5 / 4$ & Kizılay \\
\hline AMV3 & $\mathrm{K}$ & 40 & Yüksek lis. & Akademisyen & $5 / 5$ & $3-4$ \\
\hline
\end{tabular}

Katılımcıların demografik özellikleri incelendiğinde, dördünün erkek, diğerlerinin kadın olduğu görülmektedir. Özellikle Iraklı katılımcıların tamamı kadındır. Bunun nedeninin Iraklı erkeklerin belli dönemlerde Irak'a çalışmaya gitmeleri olabilir (Veli ifadelerine dayalı yazar yorumu). Katılımcılardan sadece bir Afgan kadın velinin okuryazar olmaması ve yedi katılımcının üniversite mezunu olması dikkate değerdir. Katılımcıların sadece üçü ev hanımı iken diğer 
katılımcıların tümü bir mesleği icra etmektedirler. Katılımcıların tümünün birden fazla çocuk sahibi oldukları ve çocukların çoğunluğunun öğrenim çağında oldukları tablodan anlaşılmaktadır. Maddi açıdan bakıldığında ise katılımcıların beşinin Kızılay kart üzerinden Sosyal Uyum Yardımı (SUY) aldıkları (kişi başı 120 tl), bir Suriyeli ve Irak'tan petrol parası alan iki Iraklı velinin diğerlerine nispeten ekonomik durumlarının iyi olduğu görülmektedir.

\section{Verilerin Toplanması}

Araştırma verilerinin elde edilmesi için araştırmacı tarafından geliştirilmiş ve nitel araştırma yöntemlerinde kullanılan yarı-yapılandırılmış görüşme formu kullanılmıştır. Araştırma konusu ile ilgili literatür taranmış ve taslak görüşme formu oluşturulmuştur. Görüşme formu kapsamı, içeriği, cümle yapısı ve tutarlığının kontrol edilmesi amacıyla tez danışmanı ve bir uzmana gönderilmiştir. Düzeltmeler doğrultusunda tamamlanan görüşme formu, araştırmacının çalıştığı okulda öğrenim gören iki mülteci öğrenci velisine ön uygulama amaçlı uygulanmıştır. Uzman görüşlerinin alınması ve ön uygulama aşamasından sonra araştırmanın etik süreçlere uygunluğunun sağlanması için Hacettepe Üniversitesi Etik Komisyon'undan izin alınmıştır. Daha sonra araştırmanın Samsun'daki okullarda uygulanabilmesi için Samsun Milli Eğitim Müdürlügüne uygulama izni için başvuru yapılmıştır. Uygulama izinlerinin alınmasından sonra görüşmelerin yapılacağı okullara gidilerek rehber öğretmenler aracılı̆̆ıyla görüşülecek kişiler belirlenip gönüllük esasına bağlı kalınarak randevu alınıp görüşmeler gerçekleştirilmiştir. Randevu alınan 4 katılımcı çeşitli kaygılar nedeniyle görüşmeye başlamamışlardır. Görüşmeler 30-50 dakika arasında sürmüştür. Görüşmeye katılan velilere görüşmelerin kayda alınmasında sakınca olup olmadığı sorulmuş, sakınca görenlerle yapılan görüşmelerde not tutulmuştur. Görüşme sırasında görüşme ile ilgili eklenmesi gereken mülakat, tutum ve davranışlar da not alınmıştır. Araştırmaya katılanlara milliyet temeli üzerinden kodlar verilmiştir. Örneğin Iraklı katılımcılar IMV1 (Iraklı mülteci veli), SMV1 (Suriyeli mülteci veli) ve AMV1 (Afganistanlı mülteci veli), isimlerin sonlarındaki sayılar $(1,2,3)$ katılımcıların sıra sayılarını ifade etmektedir.

\section{Verilerin Analizi}

Nitel veri analizinde toplanan verilerin sistematik hale getirilmesi, kodlanmas1 ve okuyucuya sunulması gerekir. Nitel çalışmalarda araştırmacı toplanan verilere dayanarak, veriler içerisindeki keşfedilmemiş bilgiyi açığa çıkarmaya gayret eder (Özdemir, 2010: 326). Bu çalışmada elde edilen veriler içerik analizi yöntemiyle çözümlenmiştir. İçerik analizi sistematik olarak ortaya konmamış verileri bir sistematiğe dökerek ortaya çıkarmaya yarayan tekniktir (Demir, 2014: 314). Araştırma verilerinin analizi için öncelikle tüm metinler yazılı hale getirilerek hızlı bir okuma yapılmış ve notlar alınmıştır. Daha sonra birbiri ile ilgili parçalar, benzer kelimeler, cümleler ve ifadelerden temalar oluşturulmuştur. Ardından araştırmaya uygun önemli verilerden alt temalar ve onlara bağlı kategoriler oluşturulmuştur. Tema ve alt temalar arasında bağlantılı olanlara karar verilmiş ve yazım aşamasına geçilmiştir.

\section{Geçerlik ve Güvenirlik}

Bu araştırma nitel bir araştırmadır. Nitel araştırmada detaylı bir şekilde deneyimlere ulaşmak amacıyla katılımcılardaki derin bilgi yapısı anlaşılmaya çalışılır (Creswel, 2013: 246-247). Bu yüzden nitel çalışmaların geçerlik ve güvenirlikleri nicel çalışmalardan farklılık gösterir (Yıldırım ve Şimşek, 2013: 289). Nitel araştırmalarda geçerlik ve güvenirlik ifadelerinin yerine güvenduyulabilirlik kavramı çerçevesinde yapılacak değerlendirmelerin bir bütünlük oluşturacağ 1 düşünülebilir. Bu doğrultuda araştırmada Miles ve Huberman'ın nitel araştırmaların geçerlik ve güvenirliğine ilişkin değerlendirmeleri baz alınıştır (2015: 277-290). Bu araştırmanın inanırlığını artırmak için veriler toplandıktan sonra araştırmacı verileri özetleyip katılımcılardan onay almıştır. Araştırmada güvenilebilirliğin artırılması için ise veri kaynakl üçgenleme yönteminden yararlanılmış, bu amaçla veri çeşitliliği sağlamak için farklı milliyetlerden mültecilerle 
görüşülmüştür. Daha sonra nitel araştırma yöntemleri konusunda uzmanlaşmış iki öğretim üyesinden araştırmayı çeşitli boyutlarıyla incelemesi istenmiştir. Araştırmanın onaylanabilir olması için ise görüşme yapılan kişilerden onay alınarak yapılan görüşmeler hem cep telefonuna hem de ses kayıt cihazına kaydedilmiştir. Aynı zamanda görüşme sürecinde kısa notlar tutulmuştur. Araştırmanın aktarılabilirliğinin sağlanması için ise, örneklem seçiminden katılımcıların özelliklerine kadar tüm bilgiler yöntem kısmında ayrıntılı olarak açıklanmıştır. Ayrıca doğrudan alıntılara sık sık başvurularak verinin doğasına sadık kalınmıştır.

\section{Bulgular}

\section{Mültecilerin Türkiye'ye göç etmelerinin nedenlerine ilişkin bulgular}

Çalışmanın katılımcıları farklı ülkelerden, farklı milliyet ve mezheplerden mülteci velilerin göç süreci ve nedenlerine ilişkin olarak birbirinden farklı deneyimler ifade etmişlerdir. Bu ifadeler savaştan kaynaklı nedenler ve diğer nedenler olarak iki alt temaya ayrılmıştır. Bu bağlamda Tablo 2'de Türkiye'ye göçün nedenlerine ilişkin kodlamalar verilmiştir.

Tablo 2: Türkiye'ye Göçün Nedenlerine İlişkin Bulgular

\begin{tabular}{cccc}
\hline \multirow{2}{*}{ Tema } & Alt Temalar & Kategoriler & Katılımcı sayısı \\
& & & \\
& Savaş ve çatışma & Güvenlik & 10 \\
kaynaklı nedenler & Yakınlık & 8 \\
Türkiye'ye göçün nedenlerine & & Ekonomi & 4 \\
\cline { 2 - 4 } ilişkin bulgular & Diğer nedenler & Müslüman ülke & 5 \\
& & Türkmenlik & 4 \\
& & Eğitim & 2 \\
\hline
\end{tabular}

Araştırmanın katılımcısı olan mülteci öğrencilerin velileri öncelikli olarak güvenlik nedeniyle ülkelerini terk ettiklerini belirtmişlerdir. Örneğin, SMV1yapılan literatür taramasında rastlanılmayan aşağıdaki değerlendirmeyi yapmıştır;

(...) Ben Suriye'den gitmek zorunda kaldım. Çünkü çok kız var. Benim beş kızım var. Savaşta kızlar çok tehlikeli. Mesela IŞID (Daeş) var, kızlarımı istedi, haber gönderdi, o almasa PKK var... Savaş kız çocukları için çok tehlikeli. Arası iyi olanların kızlarını almıyorlar. Kız çocuklarım olmasaydı belki de terk etmezdim ülkemi...

Aynı kişi savaş başladıktan sonra yaşamın herkes için zor olmaya başladığını, Suriye'de iken çok zengin olduğunu, inşaat firması sahibi olduğunu ve her şeyini yok pahasına satıp yakın ve güvenli olduğu için Türkiye'ye sığındığını belirtmiştir. İç savaş ve çatışmaların yaşandığı diğer ülke Irak'tan gelen IMV1 kodlu katılımcı ise Irakta yaşanan sürekli çatışma ve terörden bıktıklarını ifade ederken aşağıdaki değerlendirmeyi yapmıştır;

(...) Ben hukuk fakültesi mezunuyum. Adalet bakanlı̆̆ında avukat olarak çalışıyordum.

İki kez bombalı terör saldırısıyla yüzleştim, üstelik hamileydim... Biz yaşamak istiyoruz, hakkımız yok mu yaşamaya. Hem savaş var hem iş yok. Eşim sünni olduğu için iş vermiyorlar. O yüzden geldik biz Türkiye'ye...

Irak'tan Türkiye'ye sığınan bir diğer katılımcı IMV2 ise “Musul'da evimiz ylkıldl, abimin çocukları öldü, nereye gidelim. Burast yakın zati. Biz Türkmen'iz ve orada can güvenliğimiz yok, Türkmen olduğumuz için hiç yok" diyerek esasen akrabalık bağına da vurgu yaparken, beraberinde yaşadıkları bölgede Türkmenlerin daha çok mağduriyet yaşadıklarını ifade etmektedir. Aynı şekilde IMV5 kodlu katılımcı da rejim, Kürtler ve DAEŞ arasında sıkıştıklarını, sokaklarda sürekli çatışma yaşandığını, Türkmenlerin daha çok tedirgin olduğunu, o nedenle çocuklarını alarak Türkiye'ye sığındığını belirtmiştir. IMV6 kodlu doktor katılımc1 ise;

(...) Benim vatanım bitti, hep düzelir diye bekledim, savaştan sonra da bekledim, herkes kaçtı Avrupa'ya, ben bekledim. Ama düzelmedi ve umudum da kalmadı. Musul'da Daeş var. Askerleri var ve herkesi çok rahat öldürüyorlar. ... Benim çocuklar hepsi okula gider, 
4 çocuk. Ben hep kaygıyla bekledim çocuklarımı, eve gelebilecekler mi diye. Sen bilir misin bunu? (gözleri doluyor). Artık bıktım. Yeter. Üç savaş yaşadım ben. Güvenli yaşamak bizim de hakkımız...

SMV3 kodlu katılımc1 ise "savaş var, zulüm var, iş yok, huzur yok, ölüm var. Ben iki erkek iki kız kardeşimi kaybettim, bombalarla öldüler. Biz kaçtık, ailenin bir kısmı Avrupa'ya kaçtı, bir kısmı ise hala yaşıyor her gün savaş olan yerde" diyerek yaşanan savaş halinin insanları evlerinden yurtlarından ayrılmak zorunda bıraktığını vurgulamıştır. Görüşmeye çok iyi Türkçe konuşan lise öğrencisi oğlu ile katılan AMV2 kodlu katılımcı ise;

\begin{abstract}
"hiç insan otuz gün yürür mü? Niye kaçtık, savaştan kaçtık, ölümden kaçtık, bombalar patladı, yakınlarımız hep öldü. Yürüdük önce Pakistan'a, sonra buraya, ayağım kırıldı yolda (ayağını gösteriyor, acılı yüz ifadesiyle) biz aç kaldık, çocuklarım aç kaldı yolda, kocam tüberküloz oldu, şimdi de gözleri görmüyor. Ama yaşıyoruz burada...
\end{abstract}

Katılımcı yukarıdaki ifadelerle her şeye rağmen kötü süreçlerden geçtikten sonra Türkiye'ye vardıklarını, eşinin rahatsız olduğunu fakat hayatta olmalarının bile olumlu olduğunu ifade etmiştir. SMV1 ile paralel görüş ifade eden SMV4 kodlu katılımcı ise "köy bombalandl, çoğu yakınımız öldü, ben çocuklarımı aldım hemen sınıra kaçtım, zaten $5 \mathrm{~km}$. yoksa çocuklarımı asker yapacaktı, PKK ya da DAEŞ" diyerek esasen yakın olduğu için Türkiye'ye sığındığını belirtmiştir. Görüşmeye lise öğrencisi kızı ile gelen IMV4 kodlu katılımcı ise çatışmalardan kaynaklı eşinin işlerinin kötüye gittiğini, onunda işini orada kapatıp Türkiye'de iş yeri açtığını şimdi durumlarının daha iyi olduğunu, yani daha çok ekonomik nedenlerden dolayı geldiklerini belirtmiştir. AMV3 kodlu katılımcı ise beş kardeş burada olduklarını, anne babasının Kabil'de yaşadıklarını ve çocuklarını o ortamdan kurtarma amacıyla tüm kardeşleriyle beraber Türkiye'ye gönderdiklerini, aynı zamanda kız kardeşlerinin Afganistan'da okula gitmelerinin zor olduğunu ifade etmiştir. Kendilerini Türklere yakın hissettiklerini, aynı zamanda Müslüman bir ülke olduğu için Türkiye’ye geldiklerini belirtmiştir. Aynı şekilde AMV1 kodlu katılımcı da "biz Afgan olsak da aynı kökeniz, Selçuklulardan itibaren akrabayız. Ama bizi istemeyen insanlar cahil, bilmiyorlar, hem de Íslam'iz diyerek" diyerek hem milliyet hem de din vurgusu yaparak, Türkiye'ye geliş nedenini din ve milliyete bağlamaktadır.

\title{
Mültecilerin eğitime erişim süreci ile ilgili deneyimleri
}

Mülteci velilerin eğitim sürecine ilişkin deneyimlerine ilişkin ifadeler çözümlendiğinde en belirgin kodlamanın dil kategorisinde olduğu görülmektedir. Özellikle çatışma ve iç savaşların başladığı 2011 yılından itibaren sürekli bir artış gösteren sığınmacıların Türkiye'de kalış süresi uzadıkça dil problemini kısmen de olsa çözdükleri görülmektedir. Velilerin eğitim sürecinde yaşadıkları problemler ve olumluluklara ilişkin kodlamalar aşağıda Tablo 3'te gösterilmiştir.

Tablo 3: Eğitime Erișim Süreci ile İlgili Deneyimlere İlișkin Bulgular

\begin{tabular}{cccc}
\hline Tema & Alt Temalar & Kategoriler & Katılımcı sayısı \\
\hline \multirow{2}{*}{$\begin{array}{c}\text { Eğitime erişim süreci ile } \\
\text { ilgili deneyimlere ilişkin } \\
\text { bulgular }\end{array}$} & Olumsuz deneyimler & Dişlanma-Horlanma & 10 \\
\cline { 2 - 3 } & Olumlu deneyimler & Şiddet & 9 \\
\hline
\end{tabular}

Araştırmanın katılımcılarının büyük bir çoğunluğu Türkiye'ye geldiklerinde ve eğitim süreçlerinde en çok karşılaştıkları problemin dil uyuşmazlığı olduğunu ifade etmişlerdir. Fakat özellikle Türkmen asıllı Iraklılar ve Özbek asıllı Afganistanlılar daha az dil problemi yaşadıklarını 
ifade etmişlerdir. İlk geldiği günlerden itibaren eğitime erişimle ilgili yaşadıkları problemi SMV1 kodlu veli şöyle ifade etmiştir;

(...) İlk zamanlarda dil olmadığı için çocuklar okula gitmek istemedi, sonra biraz öğrenince gittiler. Okula gidince bazı Türk öğrenciler benim kızlara kızmış, yüksek not aldı, nasıl aldı, kopya çekti dedi, kızlarım çok çalı̧̧kandır ama. Ama öğretmen çok iyi, şimdi sınıfta hiç sıkıntı yok. Küçük kızım çok kü̧̈ük geldi buraya, Türkçeyi çok iyi bilir, sabah okula gitmek için erkenden kalkar. Çok seviyor okulu. Ama ilk zamanlarda diğer çocuklarım çok sıkıntı çekti. Bazı öğrenciler onlara çok kötü davranıyor, gidin diyor, kötü bakıyor (yüzünde sert bakışla göstermeye çalışıyor). Ama azı (konuşmasının bütününde "bazıları", "çok azı" ifadelerini çok vurguluyor). Hâlbuki eğitim aynı altın, her zaman kazanır, öğrenir meslek, öğrenir dil. Eğitim aynı bina (odadaki kolonları gösteriyor) eğitim yükseltir, kolon olmazsa çöker, varsa yükselir...

Sosyo-ekonomik düzeyi düşük bir semtte yaşayan ve aynı semtteki okula çocuğu devam eden SMV2 kodlu katılımc1, ilkokul 4. Sınıfa giden oğlu ile görüşmeye geliyor. Oğlu tercümanlık yapıyor fakat annenin de Türkçesi iyi. Aşağıdaki şekilde bir değerlendirme yapıyor;

(...) Oğlum okulda çok horlanıyor, eve gelince sürekli ağlıyor, okulda sürekli şiddete uğruyor, arkadaşları zorbalık yapıyor (oğlu diyor), oyunlarına almıyorlar, çok çalışkan olduğu için onu kıskanıyorlar, alay ediyorlar, arkadaşları sınıfta oğluma dilenci diyorlarmış, eve gelince ben ölmek istiyorum diyor, okulda şiddet görüyor gelip evdeki dört yaşındaki kardeşini dövüyor... Biz zorunlu olduğumuz için geldik, niye böyle yapıyorlar, bize burada da rahat yok (anne çok gergin görüşme boyunca çok ağladı). (Görüşme sırasında teneffüs zili çalıyor, çocuğa dışarı çıkıp oynayabileceğini söylüyorum, gözleri doluyor ve kimse benimle arkadaşlık yapmıyor ki, kimle oynayayım diyor). Bir de öğretmeni çok iyi, sınıfla konuşuyormuş öyle yapmasınlar diye, kötü çocuklar yine sataşıyor, fakir, fakir diye alay ediyorlar oğlumla....

Türkiye'ye eğitim amaçlı gelip kalan mültecilerden biri olan 3 çocuklu AMV1 kodlu veli esasen kendisinin de bir öğrenci olduğunu, yüksek lisans ve doktora eğitimini burada yaptığını ama dönmeyeceğini belirtirken, eğitime erişim için ücret ödemesi gerekliliğinin kendilerini çok zorladığını ifade ederek aşağıdaki çarpıcı değerlendirmeyi yapmıştır;

(...) En büyük sıkıntı çocuğumla dalga geçmeleri, fakirliğimizle dalga geçmeleri, 3. sınıf öğrencisi kızım, o yaştaki çocuklar nasıl bu kadar kötü olabiliyor anlamıyorum, kızım hep ağlıyor. Sen Türk değilsin git diyormuş arkadaşları. Ben de ona dedim ki, "biz Özbek Türküyüz de onlara, esas Türk biziz”. Sabret diyorum kızıma sürekli, o da sabrediyor. Allahtan öğretmeni çok iyi, çok uğraşıyor sınıfı alıştırmak için ama herhalde onların anne babaları kötü. Beni bile kabul edemedi koca koca adamlar mahallede. Ev sahibim olmasaydı bana da kötü davranırlardı, o hep benimle gezdi, camiye beraber gittik, sonra dost olduk. Ama bu civarda oturanlar eğitimsiz cahil insanlar, o yüzden de normal. Onlar İslam kardeşliğini de bilmiyorlar. Kızımın sınıfındaki Suriyelilere de kötü davranıyorlar ama...

Türkiye'ye 2012 yılında gelen IMV1 kodlu veli de ilk geldikleri dönemde ülkedeki mülteci yabancı sayısının az olmasından kaynaklı çok tepki görmediklerini fakat mülteci sayısının hızla artmasının kendilerine yönelen kötü davranışları körüklediğini belirterek aşağıdaki değerlendirmeyi yapmıştır;

(...) dil sorunumuz yok, çünkü 8 yıl oldu geleli. Ama her gün çocuklarıma yönelen tepki, şiddet, horlanma artıyor. Türk değilsiniz gidin diyorlarmış, fakir diyorlarmış. En çok kızdığımız "pislik" demeleri. Yolda gördüklerinde de "pislik" niye diyor ki... Sınıfta kavga çıkınca diğer çocukların anneleri gelip bizim çocuklarımızı dövüyor, pislikler gidin bu ülke bizim diyorlar... Öğretmeni de dinlemiyorlar onlar. Öğretmen çok iyi. Büyük çocuğumu da aynı öğretmen okuttu... 
Çocuklarının Türkçelerinin iyi olduğunu, eğitime erişim ve eğitim süreci ile ilgili hiçbir sıkıntı yaşamadığını belirten IMV4, IMV5, SMV4, SMV5 ve AMV3 kodlu veliler özellikle öğretmenlerden kaynaklı olarak sınıfta sıkıntı olmadığını ifade ederken, IMV6 kodlu veli görüşmenin yapıldığı okulda okuyan kızının özellikle üç öğretmen tarafından "hala gitmediniz mi" diyerek sürekli taciz edildiğini belirtmiştir. AMV2 kodlu veli de "Türkmen olduğumuz için okulda kötü davranmıyorlar ama Arap olanları dövmüşler sınıfta, oğlum ayırırken onu da dövmüşler" demiştir. IMV3 kodlu veli ise "büyük çocuklarının Iraklıların özel okullarına gittiğini, küçük kızının ise Türk okuluna gittiğini ve çok mutlu olduğunu, büyük çocuklarının Türk okulunda şiddete uğrayacakları kaygısıyla Irak okulunu istediklerini" ifade etmiştir. SMV3 kodlu veli ise "benim torunum sarışın ve Türk' e benzediği için, hem de çok güzel Türkçe konuştuğu için horlanmıyor ve şiddete uğramıyor, Arap olsaydı ve ya Arapça konuşsaydı eminim onu da döverlerdi" şeklinde ifadede bulunmuştur. IMV2 kodlu veli Türk halkının kötü olmadığını, 3 kardeşinin 4. 7. ve 12. sınıfta öğrenci olduğunu, sınıflardaki sadece birkaç öğrencinin kötü davrandığını ve onların velilerinin de kötü olduğunu ifade etmiştir. Arkadaşlarının ve bazı velilerin kötü davranışları yüzünden kardeşlerinin okula gitmek istemediğini belirtmiştir.

\section{Mültecilerin toplumla uyumu ve kabullenilme ile ilgili yaşadıkları deneyimler}

Toplumsal huzurun ve barışın sağlanabilmesi için ülkede yaşaya $\mathrm{n}$ insanların birbirleriyle uyumun sağlanması kaçınılmazdır. Aksi takdirde kişiler arasında yaşanan bireysel çatışmalar toplumsal boyuta evrilebilir ve istenmeyen olaylar yaşanabilir. Türkiye'ye gelen mültecilerin uyum ve kabullenilme noktasında yaşadıkları deneyimler Tablo 4'teki gibi temalandırılmıştır.

Tablo 4: Mültecilerin Topluma Uyumu ve Kabullenilme Deneyimleri

\begin{tabular}{cccc}
\hline Tema & Alt Temalar & Kategoriler & Katılımcı sayısı \\
& & Hor görülme & 10 \\
& & Şiddet & 8 \\
Mültecilerin topluma & Dişlanma & İş vermeme-düşük maaş & 8 \\
uyumu ve kabullenilme & & Selamlaşmama & 7 \\
deneyimlerine ilişkin & & Korku & 7 \\
\cline { 2 - 4 } bulgular & Kabullenilme & İyi işverenler & 5 \\
& & Yardımsever komşular & 4 \\
\hline
\end{tabular}

Araştırmaya katılanların büyük çoğunluğu görüşme başladığı anda, Türkiye'de bir sıkıntı ya da olumsuz bir durum yaşamadıklarını ifade etmiş, fakat görüşme ilerledikçe güven ve samimiyet duygusu görüşmeye hakim olunca çok ciddi dışlanmaya ve ötekileştirilmeye uğradıklarını ifade etmişlerdir. Örneğin SMV2 kodlu kadın katılımcı;

(...) Geldiğimizden beri şiddet içerisindeyiz. Eşime şiddet uyguladılar, parasını aldılar, dövdüler, ama kötü insanlar. Herkes kötü değil. Mahallede hiç kimse bizimle konuşmuyor, selam vermiyor ve çok kötü bakıyorlar. Biz burada artık çok korkuyoruz. Düşmanca bakıyorlar, hissediyorsun (...) Oğlumun arkadaşları bile çok kötü. Küçük çocuklar ama zorbalık yapıyorlar...

SMV1 kodlu mülteci ise "Bazı insanlar bize kötü resimli (yüz ifadesi) baklyor. Ben Müslüman sen Müslüman niye ki... Ama komşularım iyi. Sokakta Arapça konuşma, bi şey yok. Ama normal, her yerde on numara insan da var, bir numara insan da" diyerek esasen herkesin kötü davranmadığını ve kendilerinin de Müslüman olduğuna vurgu yaparak dışlanmanın olmaması gerekliliğini aynı dine mensubiyet üzerinden tariflemiştir. Aynı katılımc1 "herkes iyi olursa Dünya cennet olur zati" ifadelerini kullanarak, tüm toplumlarda iyi ve kötü insan olabileceği vurgusu yapmıştır. AMV1 kodlu katılımcı ise aşağıdaki daha çarpıcı değerlendirmeyi yapmıştır; 
(...) Kimse bize iş vermiyor. Vatandaşlık yok. Ben Türkiye İslam diye Avrupa’ya gitmedim. Arkadaşlarım gitti, şimdi onlar bana gülüyor, çünkü durumları çok iyi. İlk geldiğimde daha kötü idi, ev sahibim olmasa benim işim çok zordu, mahalleye, camiye o götürdü beni... Şimdi sana bir şey anlatayım. Bir gün dolmuş kuyruğunda bekliyorum, genç bir çocuk geldi önüme geçti. Bende uyardım, dedim sıra var yerine geç. $\mathrm{O}$ da bana dedi ki, biz Türk'üz sen değilsin, benim önümde duramazsın dedi ve geçmedi yerine. Ben çok üzüldüm. (Yüz ifadesi üzgün ve gözleri dolu). Ama en çok oradaki hiç kimse onu uyarmadı, ona kızmadı, ona üzüldüm esas. İşte bu dışlanmadır. Bir atasözü var, der ki; “Gurbet insanı yavaş yavaş öldürür” Biz onu yaşıyoruz...

IMV1 kodlu katılımeı ilk geldikleri yıllarda çok iyi komşuluk ilişkileri yaşandığını, komşularının mobilya, yemek, soba vs. verdiklerini, sosyal olarak çok iyi ilişkiler kurduklarını fakat sonra gelen Arap sayısı artınca ilişkilerin kesildiğini aşağıdaki gibi ifade etmiştir;

“... Ben diyorum günaydın, hiç bakmıyor, çocuklarıma bağırıyorlar komşular, dışarı çıkmayın diyor, korkudan evden çıkamıyor çocuklar. Bir Ramazan akşamı çocuklarımı şuradaki (eliyle okulun yanındaki marketi gösteriyor) markete gönderdim. Büyük kızım genellikle sokakta Arapça konuşmamaya dikkat eder. Küçük kızım Arapça bir şey söylemiş ve oradakiler nasıl bağırmışlar. (Hayret ifadesi, gözleri büyüyor). Burası Türkiye, burada Türkçe konuşacaksınız diye. Çocuklar gece boyu korkudan ağladı. (kendi de ağlıyor). Bir de sınıfın Whatsapp grubu var. Orada bize nasıl hakaretler ediyorlar bilseniz. Çocuklar değil, anne babaları. (O sırada cep telefonundan mesajları gösteriyor, gerçekten çok hakaretamiz cümleler, gidin ülkemizden pislikler, size bakmak zorunda mıyı gibi cümleler var). Anne baba öyle olunca çocuklar tabi ki kötü olur değil mi?

SMV3, IMV2, IMV3, AMV2, IMV4 ve IMV6 kodlu kat1lımc1lar eğer sokakta Arapça konuşmazlar ise bir sıkıntı yaşanmadığını ifade etmişlerdir. Bununla beraber IMV2 kodlu katılımcı çalışma arkadaşlarının kendini kıskandığını, çünkü başarılı bir satış elemanı olduğu için patronunun onu șef yaptığını, Türk'e benzediği içinde bir sıkıntı yaşamadığını belirtmiştir. SMV4 kodlu katılımc1 da "Suriyeli olduğumuz anlaşılmazsa bir sıkıntı yok, anlaşılırsa o zaman kötü işte" diyerek yabanc1 olmanın zorluğuna vurgu yapmıştır. IMV5 kodlu Türkmen katılımcı ise kendilerinin değil ama Arapların dışlandığını, bunun nedeninin de biraz kendileri olduğunu "çünkü sokaklarda ve sahillerde saçma sapan hareketler yapıyorlar, mangal yapıyor, nargile içiyor, birbirlerinin kafasını kesiyorlar, o nedenle de kimse sevmiyor onlart. Hatta ben bile" diyerek kendisinin de bu durumdan hoşnut olmadığını belirtmiştir. SMV5 kodlu katılımcı ise, patronunun ve bazı müşterilerin çok iyi davrandıklarını, bazılarının acıyarak baktıklarını fakat acınma istemediğini ifade ederek aşağıdaki değerlendirmeyi yapmıştır;

“... Bu mahalle kötü (yaşadığı mahalle). Sokaktan korkarak geldim (yoksul ve sosyoekonomik düzeyi kötü bir mahalle, çingeneler yoğun yaşıyor, ama ev kiraları ucuz), niye buradasınız gidin diye bağırıyor. İş yerinde on beş kişi çalışıyor, 3 kişi sürekli soruyor ne zaman gidiyorsun diye. Savaş bitsin ben zaten giderim. "Bizim askerlerimiz sizin için ölüyor, siz burada keyif yapıyorsunuz" diyorlar. Eğer şehit cenazesi varsa çok kötü işte. Hiç dışarı çıkmam. Mangal yapanlar, nargile içenler Suriyeli değil Iraklı. Ama bize kızıyorlar. Kötü bir şey olunca hemen Suriyeli yapmıştır diyorlar... Bazen iş yerine gelen müşteri yabancı olduğumu anlayınca soruyor hemen; sen nereli?,,,hı hı1. Sonra diyor ki savaş bitince git. Savaş biterse, evim kalırsa (yıkılmamış olursa) giderim tabi, ama Suriye'de savaş bitmez...

Afganistan'da Türkçe kursuna giden ve çok iyi Türkçe konuşan AMV3 kodlu katılımcı ise aşağıdaki çarpıcı değerlendirmeyi yapıyor;

(...) insanlar doğacakları yeri kendileri seçmiyor, düşmanlık çok saçma. Biraz anlıyorum, çünkü Türkiye'de çok yabancı var...Siz tramvaya bir binin görün ayrımcılığı. Ben her bindiğimde görüyorum. Eğer bir yabancı Arap, Suriyeli, Afgan ve ya başka milletten biri koltuklarda oturursa, hemen bağırırlar, kalkın diye. Çok yaşlı bir Arap kadın oturuyordu 
mavi koltuklarda (tramvayda), sonra bir Türk anne iki-üç yaşındaki çocuğu otursun diye o yaşlı kadını kaldırdı, ama kadın çok yaşlı (hayret ifadesi var yüzünde) çocuk bebek daha. Kadına baktım ben, çok sessiz sessiz ağladı ve kimse bir şey demedi. Ben yabancı olmasam ben derdim...

\section{Mültecilerin sosyal içerilme beklentileri}

Çalışmaya katılan mülteci velilerin ifadeleri analiz edildiğinde devletten ve toplumdan beklentiler adı altında iki alt tema belirlenmiştir. $\mathrm{Bu}$ alt temalara uygun kategoriler ise, Türk vatandaşı olma talebi, sigortalı bir işte çalışabilme, ücretsiz sağlık ve eğitim, para yardımı ve Türk vatandaşlarının sahip olduğu tüm haklara sahip olma isteği ve beklentisi olarak altı kategoride incelenmiştir. Toplumdan beklentiler ise; komşuluk ilişkilerinin yaygınlaştırılması, daha fazla saygı ve kötü bakmama olarak üç başlikta incelenmiştir. Tablo 5'te tema ve alt temalar kategorilendirilmiştir.

Tablo 5: Mültecilerin Sosyal İçerilme Beklentileri

\begin{tabular}{|c|c|c|c|}
\hline Tema & Alt Temalar & Kategoriler & Katılımcı sayısı \\
\hline \multirow{8}{*}{$\begin{array}{l}\text { Mültecilerin Türk } \\
\text { devletinden ve } \\
\text { toplumundan sosyal } \\
\text { içerilme beklentilerine } \\
\text { ilişkin bulgular }\end{array}$} & \multirow{5}{*}{ Devletten beklenti } & Vatandaşlık & 12 \\
\hline & & Sigortalı İş & 11 \\
\hline & & Sağlık (ücretsiz) & 8 \\
\hline & & Eğitim (ücretsiz) & 6 \\
\hline & & Para yardımı & 6 \\
\hline & \multirow{3}{*}{ Toplumdan beklenti } & Komşuluk & 9 \\
\hline & & Sayg1 & 9 \\
\hline & & Hor görülmeme & 8 \\
\hline
\end{tabular}

Araştırmanın katılımcıları görüşme başlangıcında öncelikle sınır kapılarını kendilerine açtığı için Türk devletine minnettar olduklarını ifade etmişlerdir. Örneğin, SMV1 kodlu katılımc1 "Türkler bizi aldığı için çok teşekkür ederiz, canımız kurtuldu. Ben çalıştığım süre bir şey istemem, para istemem, okul olsun, hastane olsun, sigorta olsun, kimlik olsun (vatandaşllk) yeter. Bir de millet kötü bakmasın yeter" şeklinde ifade etmiştir. SMV2 kodlu kadın katılımcı ise "ben iş istemem yeter ki kocamın işi olsun, sigortası olsun, iki çocuklulara da para versinler (üç çocuklulara para yardımı yaplliyormuş), vatandaşlı da istemem, memleket düzelirse geri döneceğim merak etmesinler (bıkkınlık ifadesi var yüzünde). Insanlar da bize kötü bakmasın, selam versin yeter" diye ifade etmiştir. Afganistan'dan gelen AMV1 kodlu katılımcı ise "Devletten Allah razı olsun, altı milyon muhacire bakar, tabi ki kolay değil. Ama Suriyelilere ve Irakllara para vermesine gerek yok, onlar çok zengin, petrolleri var, bizim hiçbir şeyimiz yok, bize para versin devlet" diyerek diğer yabancılardan ziyade Afganistanlıların daha kötü ekonomik koşullarda olduklarını vurgulamıştır. Ayrıca “ doktoralıyım, inşaatta çalışıyorum, sigortalı bir iş, öğretmenlik versin. Halk bize hem kötü bakıyor hem acıyor. Mesela yardım için yırtık ayakkabı getiriyor, niye bunu yapıyor, onur kırıcı. Hele belediyeler hiç yardım yapmiyor" diyerek yerel yönetimleri de eleştirmiştir. IMV1 kodlu katılımcı ise önce devlete teşekkür ettiklerini belirttikten sonra aşağıdaki çarpıcı ifadeleri kullanıyor;

(...) Biz buraya isteyerek gelmedik. Burada iş yapıp yaşamak istiyoruz. Biz kendimiz iş açtık, sürekli belediye ceza kesti, her gün her gün. Bizde kapattık. Mesela Arapça tabela yasak, İngilizce tabela serbest, böyle olur mu? Burası Müslüman ülke değil mi? Böyle olmamalı... Devlet bize okul veriyor, Allah razı olsun, ama insanlar (veliler, çocuklar) çok kötü davranıyor. İlk geldiğimizde komşuluk vardı, yine olsun. İnsanlar bize kötü bakıyor, ilk geldiğimizde yoktu. Biz saygı, sevgi istiyoruz, kimlik, vatandaşlık istiyoruz. Hastaneye gidiyorsun güzel ama doktor bakmıyor, oradan oraya gönderiyor, sonuç yok. 
Ayıptır. İlaçlar da çok para. Okul var ama kitaplar çok para. (yardımcı kitaplar). Dört çocuğum okuyor nereden bulayım ben o kadar para." (anlattıkça öfkesi artıyor)...

IMV2 ve IMV5 kodlu katılımcılar, "Türkmen oldukları için en çok vatandaşlı̆̆ı kendilerinin hak ettiklerini (hatta devletin onlara vatandaşlık vermek zorunda olduğunu) geri dönmelerinin artık mümkün olmadı̆̆ını, kendilerine Suriyelilere gösterilen ilginin yarısının gösterilmediğini ifade etmişlerdir." Türkmen olmalarına rağmen devlet dairelerinde Araplarla aynı muameleye maruz kalmalarının kendilerini çok üzdüğünü belirten IMV5 kodlu katılımc1 "ben göçmen statüsünü bile kabul etmedim, buradaki Türk'ün ne hakkl varsa hepsini bize vermek zorundalar" diyerek ayrıcalık talep ettiklerini ifade etmiştir. IMV3 kodlu katılımcı (doktor ve çok iyi Türkçe konuşuyor) öncelikle devlete açık kapı politikasından dolayı teşekkür ettiğini ifade etmiş, ardından aşağıdaki değerlendirmeyi yapmıştır;

(...) Bize yabancı gözüyle bakıp bizi istemeyenlere şunu söylemek isterim, kimse ülkesini isteyerek terk etmez. Ben düzelir diye kaç yll bekledim. (2018'de gelmiş). Bir şeyler sizi iter. Benim dört çocuğum var, akşam eve gelebilecekler mi diye sürekli kaygıyla beklemek ne zordur bilirler mi? Ben doktorum, eşim mühendis, çok iyi maaşlarımız vardı. Bıraktık gelmek zorunda kaldık. Yaşamak istiyoruz... Para falan istemiyorum. Çocuklarım ve biz çok rahat geziyoruz burada. Devletten isteğimiz bize çalışma imkanı sunsun. Ama iyi olanlara, okumuş ve mesleği olanlara vatandaşlık versin. Kötüleri ve suç işleyenleri geri göndersin. Bizi zorla geri göndermesin. Psikolojim bozuldu benim...

Suriye'den gelen ekonomik durumu kısmen iyi olan SMV3 kodlu kat1lımc1 da "para istemediklerini, ama geri dönmek de istemediklerini, vatandaşlık verilmesinin kendileri için yeterli olacağını ifade etmiştir”. Görünüm olarak Türklere benzediği için ve Türkçe bildiği için bir sıkıntı yaşamadığını ifade eden katılımcı "eğer sokakta Arapça konuşmazsanız hiç sıkıntı olmaz" diyerek Türklerde Araplara karşı bir refleks oluştuğunu belirtmiş̧tir. Çalışmaya katılan AMV2 kodlu yürüyerek Türkiye'ye gelen katılımc1 "devlet bizi geri göndermesin, çok zor geldik, bize vatandaşlık versin, eşim çok hasta ilaç versin. İnsanlar bize çok kötü bakıyor, biz de Müslümanız. Bize iş versin çalışalım, yardımlarla yaşamak istemiyoruz. Biz fakiriz biliyoruz kendimizi." diyerek geri gönderilme kaygısına vurgu yapmıştır. SMV4 kodlu katılımcı da IMV1 kodlu katılımcıya benzer şekilde sağlık hizmetlerine erişim ve ilaç alımında sıkıntı yaşadığını şu cümlelerle ifade etmiştir;

Belim kırıldı daha önce inşaattan düştüm (cep telefonundan röntgen resmini gösteriyor). Doktora gittim, fizik tedavi olmam lazım, oradan oraya gönderiyor, hala vermiyor, git ameliyat ol diyor. Doktor bedava ama ilaç paralı. Vatandaşlık olsa, sigortalı iş olsa çok iyi olacak. Şimdi inşaatta çalışıyorum (çalıştırıyorlar) iş bitti para istiyorum, para yok müteahhit iflas etti diyorlar, para vermiyorlar. Yabancıyız ya ondan. Kimseye de şikâyet edemiyoruz. Simit satmak istiyorum, diğer simitçiler kızıyor, sattırmıyor. Ben aç mı kalayım? Sabrediyorum.

IMV6 kodlu katılımeı diğer Türkmen katılımcılar gibi özgüvenli değil ifadelerinde ve görüşme sürecinde. Altı çocuğunun da öğrenci olması kaygılarını çok artırmakta. Aşağıdaki değerlendirmeyi yapıyor;

(...) biz Türkmen'iz, bize gidin diyorlar, nereye gideceğim. Yurt mu kaldı. Biz Arapça konuşmuyoruz ki. Çocuklarım korkudan dışarı çıkmıyor, parka gitmiyor. Gittikleri zaman ben çok tedirgin oluyorum, sürekli arıyorum nerede kaldınız diye. Böyle olmaz ki, biz ne yaptık. Biz de Osmanlıyız... Ben sinüzitim, hastaneye gidince ilaç alırken çok para ödüyoruz. Sigorta olsa, vatandaş olsak ödemeyiz.... Komşularım çocuklarımı dışarda görse bağırıyor, niye anlamadım. Komşuluk yok, selam yok. Okullarda kardeş olmak öğretilsin çocuklara.

SMV5 kodlu katılımeı IMV3 kodlu katılımcıya benzer şekilde herkese vatandaşlık verilmemesi gerektiğini, iyi olanlara ve mesleği olanlara verilmesi gerektiğini aşağıdaki şekilde ifade etmektedir; 
(...) Devlet herkese vatandaşlık veremez, kime verecek. Herkesi takip edecek, iyi olanları ve mesleği olanlara vatandaşlık verecek. Sonra iş, sigorta verecek... Türkler çok iyi insanlar. Tamam, bizde kötü insanlar var. Türklerde yok mu? Var. Suriyelilerle bir sıkıntı olduğunda hemen saldırmasınlar. Bize söylesinler, biz çözeriz, hemen kavga olmasın... Türk anne babalar çocuklarına bizden iyi bahsetsin, kötü bahsedince çocuklar okulda düşman oluyor, şiddet uyguluyor, kötü gözle bakıyor. Yazıktır... Ama Samsun'da az Suriyeli var, az kavga var. Çok Iraklı var, çok kavga var. Ben bugün pazara gittim, bir şeyler aldım, usta sordu (pazarcı demek istiyor); sen Suriyeli misin? Evet dedim, inanmadı. Sen Türk'sün dedi (çok hoşnut Türk'e benzetilmekten). Valla yok dedim. Çalışıyor musun dedi? Evet dedim. Çok sevindi mesela. İyi olanlar da çok, bizi de seviyorlar.

AMV3 kodlu katılımc1 ise bir ülkede herkesin sağlık güvencesi olması gerektiğini, çünkü çok pahalı olduğunu ifade etmiş, " sadece Afganlara değil herkese eğitim (yüksek öğretim) hakk1 verilmeli, kontenjanlar çok az, yeterli değil, okul bitince herkese eşit iş imkanı verilmeli, Türklerin ne hakkı varsa bizimde olmalı" şeklinde düşüncelerini ifade ederek milliyet kaynaklı bir ayrım olmaması gerektiğine vurgu yapmıştır.

\section{Tartışma, Sonuç, Öneriler}

Türkiye 2011 yılından bugüne özellikle Ortadoğu ülkelerde yaşanan savaş ve çatışmalardan kaynaklı yoğun göçlere maruz kalmaktadır. Yaşan göçler sonucunca dört milyonun üzerinde farklı milliyetlerden mülteciyi barındırmaya çalışmaktadır. Ülkedeki uyum ve huzurun sağlanabilmesi için bazı bazı politikaların hayata geçirilmesi gerekliliği ile beraber mültecilerin de beklentilerinin karşılanması gerekmektedir. Bu araştırmada Türkiye'deki mültecilerin eğitime erişimleri sürecinde yaşadıkları deneyimler ve sosyal içerilme beklentilerini açığa çıkarmak amaçlanmıştır.

Araştırmanın ilk teması olan “mültecilerin Türkiye’ye göçmelerinin nedenlerine ilişkin bulgular" değerlendirildiğinde, mülteci velilerin göç etmelerinin temel nedeninin savaşlar ve çatışmalar olduğu görülmektedir. Howard'da (2017: 1) yüzyıllar boyunca, savaşın kitlesel göçlerin ardındaki ana ve çoğunlukla itici güç olduğunu ifade etmiştir. Bu temaya bağlı olarak güvenlik, yakınlık ve ekonomi kategorileri açığa çıkmıştır. İlgili alan yazına bakıldığında ikinci dünya savaşından sonra yaklaşık 15 milyon kişinin savaş ve güvenlik kaygısıyla yer değiştirdikleri, bu yer değişikliklerinin Almanya, Polonya ve eski Çekoslovakya ülkelerinin sınırlarının değişmesine neden olduğu görülmektedir (Stalker, 2002:152). Anadolu'ya yönelik olarak yaşanan ilk kitlesel büyük göçün ise Çarlık Rusya'sının 1783 yılında Kırım'ı ele geçirmesiyle bir milyonun üzerinde Kırım Tatarının göçü ve Osmanlı-Rus savaşı sonrasında ise yine aynı sayıda Gürcü'nün göç etmesi ile başladığı görülmektedir. Cumhuriyet döneminde ise savaş ve çatışma kaynaklı en büyük göç, Bulgaristan'dan yaklaşık 800 bin kişinin Türkiye'ye göçüdür. Yine İran İslam devrimi sonras1 çoğunluğu Azeri, Fars ve Kürt olmak üzere bir milyona yakın insan Türkiye'ye göç etmiştir. Daha sonra 1988 yılında Irak'ta yaşanan Halepçe katliamı ve 1991'deki Körfez savaşından sonra da Türkiye'ye yaklaşık 500 bin kişi göç etmiştir. Son olarak ise 2011 yılında Ortadoğu'da yaşanan çatışma ve savaşlar Türkiye'ye 6 milyon civarında insanın göç etmesine neden olmuştur (Göç İdaresi, 2020). Bu değerlendirme ve göç edenlere bakıldığında mültecilerin ülkelerini terk etmelerinin temel nedeninin savaşlar ve çatışmalar, Türkiye'ye göç etmelerinin temel nedeninin ise hepsinin Müslüman olmasıdır. Bu araştırmada görüşme yapılanların da hepsi Müslümandır. Bu veri Doğanay'ın (1996), “Türkiye'ye göçmen olarak gelenlerin yerleşimi” isimli çalışmasıyla örtüşmektedir. Doğanay, Türkiye'ye göç edenlerin tümünün Müslüman ve şive farklılıkları olsa da Türkçe konuştuklarını veya Türk dilinin akrabası olan dilleri konuştuklarını vurgulamıştır. Araştırma verilerinden ulaşılan bir diğer veri ekonomik nedenlerdir. Göçe neden olan önemli faktörlerden biri de kendi ülkelerindeki bireyleri etkileyebilecek ekonomik zorluklardır (Giovetti, 2019). Türkiye'ye göç eden mülteciler ülkelerinde yaşanan savaş ve çatışmalardan dolayı ekonomik sıkıntılara düştüklerini ve bu nedenle göç ettiklerini ifade etmişlerdir. Irmak, Bilginer ve Çetin'in (2018: 87- 
98) yaptıkları çalışmada ise Türkmenlerin Türkiye'ye göç etmelerinin temel nedeninin Irakta yaşanan savaşlar ve siyasi baskılarla Türkiye'nin "Türk ve Müslüman olması"dır. Yine benzer bir şekilde Tufan (2001: 76)' da yaptığı çalışmada, Türkmenlerin anavatan olarak Türkiye'yi gördükleri, aynı dili konuşmalarının, aynı geleneğe sahip olmalarının ve aynı dine mensup olunmasının Türkiye'ye göç nedeni olduğunu belirtmişlerdir. Bu sonuçlar bizim çalışmamızda açığa çıkan bulgularla örtüşmektedir.

Araştırmanın sonucunda elde edilen bulgulardan biri de, "mülteci velilerin eğitime erişimle ilgili yaşadıkları deneyimlere" ilişkindir. Mülteci veliler eğitime erişimle ilgili yaşadıkları en önemli sorunun "dil" olduğunu vurgulamışlardır. Dil problemi mültecilerle ilgili yapılan çalışmalarda da öne çıkan bir sorundur (Erdem, 2017; Gün ve Baldık, 2017; Kardeş ve Akman, 2018; Moralı, 2018; Omidvar ve Richmond, 2003; Şahin ve Doğan, 2018; Tunga, Engin ve Çăğltay, 2020). Omidvar ve Richmond çalışmalarında dil yetersizliğinin eğitimle beraber uyum ve istihdamda da önemli bir problem olduğunu vurgulamışlardır. Göç edilen ülkenin dilinin öğrenilmemesi sadece eğitim alanında değil yaşamın tüm alanlarında ve uyumun sağlanmasında mülteciler için bir problemdir (Şahin, 2020). Türkiye, Geçici koruma kapsamındaki çocukların Türkçe öğrenimini hızlandırmak amacıyla Suriyeli Çocukların Türk Eğitim Sistemine Entegrasyonunun Desteklenmesi Projesi (PIKTES)'ni hayata geçirmiştir. Bu proje ile Türkçe bilmeyen yabanc1 uyruklu öğrencilerin Türkçe öğrenerek diğer branş derslerini alabilecek akademik yeterliliğe sahip olmaları amaçlanmıştır (PIKKTES, 2020). Araştırma bulgularında kültürel farklılıkların eğitime erişimde sorun olarak açığa çıktığı görülmektedir. Nitekim Erdoğan'ın (2015: 17) yaptığı geniş kapsamlı araştırmasının sonuçları bu bulguları doğrulamaktadır. Yapılan araştırmada Erdoğan, Türk toplumunun Suriyelilerle arasına kültürel mesafe koyduğunu açığa çıkarırken, Kardeş ve Akman (2018: 1231) ise kültürel farklılıkların mülteci çocukların eğitimi için engel teşkil ettiğini vurgulamıştır. Araştırmada bir diğer bulgu, mülteci öğrencilerin sınıf arkadaşları ve bazı öğretmenleri tarafından dışlandıklarıdır. Raabe (2018: 4) mülteci öğrencilerin eğitim süreçlerinde daha çok sınıf arkadaşları tarafindan dışlandığını bulgulamıştır. Kummitta (2015: 5-6) ise toplumsal uyumun sağlanması için dışlanmanın aksine tüm çocukların kendilerini ve yeteneklerini geliştirebilecekleri eğitim süreçlerine katılımlarının artırılması gerektiğini vurgulamıştır. Biasutti, Concina ve Frate (2019), mülteci öğrencilerle eğitim sürecine dahil olacak öğretmenlerin farklı dil ve kültürlerde eğitim ve davranışlarla ilgili eğitim almaları gerektiğini belirtmişlerdir. Araştırmacılar bu gruplarla ders yapan eğitimcilerin sosyal içermenin ve etkileşimin sağlanması için sürekli yenilikçi metodlar geliştirmeleri gerektiğini vurgulamışlardır.

Araştırmada elde edilen bir diğer bulgu mülteci öğrencilerin şiddet görmesine ilişkindir. Araştırmada mülteci öğrencilerin fiziksel veya psikolojik şiddete maruz kaldıkları görülmektedir. Raabe (2018: 4-6) son zamanlarda yapılan araştırmaların zorbalık ve etkilerine odaklanıldığını, arkadaşlık ilişkilerinde zorbalığın bir dışlanma göstergesi olduğunu, arkadaşlıktan kaçınmanın da bir çeşit zorbalık olduğunu ve eğitimsel başarıyı düşürdüğünü vurgulamıştır. Şimşir ve Dilmaç (2018: 1126-1127) ise yaptıkları araştırmada Türk öğrencilerin zaman zaman mülteci öğrencilere şiddet uyguladıklarını bulgulamışlardır. Bununla beraber, pek çok araştırma, mülteci öğrencilerin kendi aralarındaki şiddetin daha yaygın olduğunu birbirleriyle sürekli kavga ettiklerini açığa çıkarmaktadır (Şahin ve Doğan, 2018; Şimşir ve Dilmaç, 2018; Kardeş ve Akman, 2018; Moral1, 2018). Araştırmalarda ayrıca, mülteci öğrencilerin şiddet eğilimli olmalarının yaşadıkları travma kaynaklı olabileceği ifade edilmiştir. Bu bölümün ikinci alt teması olan "mülteci velilerin eğitime erişim süreci ile ilgili olumlu deneyimler" kategorisinde yer alan olumlu öğretmen tutumuna ilişkin görüşlere bakıldığında, mülteci velilerin büyük çoğunluğunun çocuklarının öğretmenlerinden memnun oldukları anlaşılmaktadır. Sağlam ve Kanbur (2017: 316-317) ve Köse, Bülbül ve Uluman (2019: 10) yaptıkları araştırmalarda, öğretmenlerin mülteci öğrencilere yönelik tutumlarının olumlu olduğu sonucuna ulaşmışlardır. Bu sonuçlar bizim çalışmamızla örtüşmektedir. Diğer kategori olan "yakın kültür ve aynı din"e mensubiyete ilişkin olarak velilerin, geldikleri ülkelerle Türkiye'yi birbirlerine 
yakın ülkeler olarak gördükleri, özellikle Osmanlı vurgusu yaparak daha önceleri aynı imparatorluk altında yaşadıklarını ifade ettikleri ve Müslümanlık ortak paydasını öne çıkardıkları görülmüştür. Bu sonuçlar ilk bölümde yer alan “Türkiye'ye göç nedenleri” temasıyla uyumluluk göstermektedir.

Mültecilerin topluma uyumu ve kabullenilme deneyimlerine ait bulgular çözümlendiğinde, araştırma katılımcısı bir kısım mültecinin ciddi şiddet gördüğü, horlandıkları ve korku içerisinde yaşadıklarını ifade ettikleri görülmektedir. Mültecilere genel olarak iş verilmediği (çalışma izni gerekli), verilse bile çok az ücret verildiği veya türlü bahanelerle hiç ücret verilmediği sonucuna ulaşılmıştır. Fernandez (2020), de İngiltere'de mültecilere yapılan ayrımcılı̆̆ 1 araştırdığ 1 çalışmasında sadece İngiltere'de değil uluslararası alanda yapılan çalışmaların da mültecilere istihdam sağlanması noktasında ayrımcılığa uğradıklarının görüldüğünü belirtmiştir. Bununla beraber mültecilerin gelişiyle özellikle yoğun olarak yaşadıkları bölgelerdeki ve ülkedeki iş gücü arzının artması ücretler üzerinde aşağı yönlü bir baskı yaratmıştır (ORSAM, 2015). Bazı işverenlerin Suriyelilerin gelişini firsat bilip işçileri düşük ücretle çalıştırdıkları da görülmektedir (Kutlu, 2019: 51). Carpio ve Wagner (2015)'in Dünya Bankası için yaptıkları araştırma ise mültecilerin esasen kayıt dışı çalışan Türk kadın işçilerin işlerini ellerinden aldıklarını, ücretlerdeki göreli düşüşün bundan kaynaklandığını açığa çıkarmıştır. Aygül (2018) ise yaptığı araştırmada, yerel halkta işsiz kalmanın müsebbibi olarak mültecilerin görüldüğünü, bu durumun onlara yönelik şiddeti artırdığını bulgulamıştır. Aygül (2018: 75) toplumda fuhuş, çok eşlilik, cinsel istismar, hırsılılı ve şiddet olayları gibi pek çok olumsuz durumun mültecilerden kaynaklandığı algısının hâkim olduğunu, bu algının yaygınlaşmasında medyanın da etkisi olduğunu vurguladığı çalışmasında, gerçek durumun öyle olmadığını, yabancıların suça karışma oranının İçişleri Bakanının açıklamasına dayandırarak \%1,2 olduğunu vurgulamıştır. Bu araştırmada elde edilen bulgularda da mülteciler şiddete uğrama nedenlerini "yerel halkın kendi işlerinin ellerinden alınması" kaynaklı olduğunu vurgulamışlardır.

Mülteci veliler yerel halk ve komşuları tarafından hor görüldüklerini ve kendilerine selam verilmediğini bundan dolayı korku ve kaygı içerisinde yaşadıklarını ifade etmişlerdir. Bu bulgu Alpman (2018: 342) tarafından desteklenmektedir. Alpman, mültecilerin göç ettikleri ülkelerdeki yerel halk tarafından ötekileştirilmeleri ve hor görülmelerini, yerel halkın kendilerini onlara karşı üst konumda görmelerinden kaynaklandığını vurgulamıştır. Çünkü mülteciler, bulundukları konum itibariyle, ekonomik, toplumsal, sosyal ve kültürel olarak zaten ötekileştirilmişlerdir. Bu ötekileştirilme onlarda korku duygusunu da beraberinde getirmektedir. Kendilerini egemen olarak gören yerel topluluklar mültecilere karşı kendi kültürlerini ve kimliklerini yüceltirken bir nevi 1rkçılık davranışı da sergilemiş olurlar (Alpman, 2018: 343). Oysa tam tersine, toplumsal bütünlüğün ve bir arada yaşamın sağlanması için, sosyal uyum, sosyal uyumun sağlanması için de toplumların birlikte yaşama arzusu duymaları ve karşılıklı etkileşimi artırmaları gerekmektedir (Bolgün ve Uçan, 2020).

Bu temaya ait bulgulara bütünlüklü bakıldığında görüşme yapılan mülteci velilerin büyük çoğunluğunun kendilerini sosyal, kültürel, toplumsal ve ekonomik olarak dışlamış hissettikleri görülmektedir. Bu bulgu Khan (2015: 31)'ın 'göçmen ve mültecilerin siyasi, sosyal, ekonomik haklardan yoksun oldukları, düşük ücretli işlerde güvencesiz olarak çalıştıkları, gecekondu semtlerinde ve şiddetle iç içe yaşayarak toplumdan dışlandıkları" bulgusuyla örtüşsmektedir. Bununla beraber araştırmaya katılan bir kısım velinin de çalıştıkları işyerlerinde çalışma arkadaşları ve patronları tarafından çok iyi karşılandığı, onlara değer verildiği, patronlarının onları dışlamadıklarını ifade ettikleri de görülmüştür. Aynı şekilde bazı veliler komşularıyla ilişkilerinin çok iyi olduğunu, komşularının özellikle ilk geldikleri dönemlerde onlara yardım ettiklerini ifade etmişlerdir.

Araştırmanın son teması mültecilerin sosyal içerilme beklentilerine dair elde edilen görüşlerden iki alt temaya ulaşılmıştır. Bunlar; mültecilerin devletten ve toplumdan beklentileridir. Mültecilerin devletten beklentileri öncelikle Türkiye Cumhuriyeti vatandaşı olabilmektir. Aksi takdirde dışlanma ve sürekli olarak geri gönderilme kaygısı yaşayacaklarını ifade etmişlerdir. İlgili 
alanyazına bakıldığında Türk (2020), Suriyeli mültecilerin geleceğe dair belirsizliklerin ortadan kalması için vatandaşlık istediklerini bulgulamıştır. Klasen (1999: 20) bir ülkede uzun süre yaşayanlara vatandaşlık hakkı verilmemesinin bir tür dışlanma sayılabileceğini, toplumsal katılım için vatandaşlık hakkının gerekli olduğunu vurgulamıştır. Khan (2015:7-10) ise, sosyal dışlanmanın vatandaşlık, katılım, demokratikleşme yoksunluğu ile bağlantılı olduğunu, vatandaşlığın bireysel ve toplu hakları kullanma yeteneği sağladığını ifade etmiştir. Kutlu (2019: 56-57) vatandaşlık tartışmalarına kamuoyunun olumsuz yaklaştığını, mültecileri vatandaşlığa geçirmenin riskli bir süreç olduğunu, eğer olursa da çok seçici davranılması gerektiğini bulgulamıştır. Araştırma bulgularında da bazı katılımcıların devletin vatandaşlık verirken seçici davranması gerektiğine dair görüşler ifade ettiği görülmektedir. Araștırmada mültecilerin beklentilerinden biri de sigortalı yani iş güvenceli çalışma talebidir. Mülteciler, (çalışanlar) kendilerinin ucuz iş gücü olarak çalıştırıldıklarını, düzenli ücret almadıklarını vurgulamışlardır. Khan (2015:7-10) güvencesiz çalıştırılmanın mültecilerin ekonomik olarak dışlanmaları anlamına geldiğini, bunun aynı zamanda kayıt dışı istihdamı artırdığını vurgulamıştır. Türkçe alanyazına bakıldığında ise Alpman (2018: 342) mültecilerin iş gücü piyasasının en altında yer alan kesimi olduğunu, eşitsiz ve dezavantajlı koşullarda çalıştıklarını, fakat başka seçenekleri olmadığı için çalışmak zorunda olduklarını bulgulamıştır. Özellikle Suriyelilerin kayıtsız, güvencesiz ve ucuz iş gücü olarak çalıştırılmalarının neticesinde yerel halkın işsizleştiği, bu durumun onlara yönelik şiddeti artırdığı, aynı zamanda ayrım yapmaksızın mültecilere karşı ırkçı kalkışmalara yol açtığı bulgulanmıştır. Bu bulgular bizim çalışmada elde ettiğimiz bulgularla örtüşmektedir.

Araştırmanın mültecilerin beklentilerine dair bir diğer bulgusu, mültecilerin ücretsiz sağlik eğitim hizmetlerine erişmeleriyle ilgilidir. Esasen Türkiye'deki mülteciler, eğitim ve sağlık hizmetlerine ücretsiz erişebilmektedir. Buradaki sorun, sağlık alanında özel hastanelerden yararlananlardan ve ilaç ücretlerinde katılım payı alınmasından kaynaklıdır. Benzer bir şekilde eğitim hizmetleri de ücretsiz karşılanmaktadır. Fakat bazı ek kaynaklar ve okulların farklı giderleri için velilerden ücret talep edilmektedir. Bu durum Türk vatandaşları için de geçerlidir. Gültaç ve Balçık (2018: 196) yaptıkları çalışmada Afet ve Acil durum Yönetimi Başkanlığı (AFAD) ve Sağlık Bakanlığının yaptıkları protokollerle mültecilerin sağlı hizmetlerine erişiminin sağlandığını belirtmişlerdir. Yazarlar mültecilerin yoğun olarak yaşadıkları 17 ilde Göçmen Sağllğı Merkezleri aracılığıyla, diğer illerde kendilerine verilen kimliklerle sağlık hizmetlerinden ücretsiz faydalanabildiklerini belirtmişlerdir. Mültecilerin ilaç giderlerinin ise \%80'i AFAD tarafından, \% 20'si ise hastanın kendisi tarafından karşılanmaktadır. Sağlık giderlerinin ise, genel sağllk sigortalıları için belirlenmiş olan tutarı kadar olan kısmı AFAD tarafından karşılanmaktadır (Kocadal, Tekin, Gökşin ve Erbaş, 2019). UNICEF'in (2019) raporuna göre Türkiye'de yaşayan yabancıların 1.74 milyonu çocuktur. Okula kayıtlı olan 680 bin öğrencinin yanı sıra yaklaşık 400 bin öğrenci eğitim süreçlerine katılmamıştır. UNESCO (2019) raporunda ise Türkiye'nin 2020 yılına kadar tüm çocukları devlet okulu sistemine dahil edileceği belirtilmiştir. Raporda beraberindeki birkaç ülke ile beraber Türkiye'nin bu süreci iyi yönettiğine vurgu yapılmıştır. Bu bulgular Türkiye'nin mültecilerin eğitiminde diğer ülkelere göre iyi bir noktada olduğunu göstermektedir.

Araştırma katılımcısı mülteci velilerin bir kısmı devletin kendilerine para yardımı yapmasını talep etmişlerdir. Bir kısmı ise çalışma izni ve ya iş verildiği sürece para talep etmediklerini belirtmişlerdir. Bununla beraber özellikle Afgan mültecilerin Irak ve Suriye'den gelenlerin zengin olduklarını, o nedenle devletin sadece kendilerine para yardımında bulunması gerektiğini ifade ettikleri görülmüştür. Türkiye'de Geçici koruma veya uluslararası koruma altında olup belli şartları (18 yaş altı en az bir çocuğu olup yalnız anne veya yalnız babalar, tek başına olup kimsesiz olan 60 yaş üzeri olanlar, \% 40 veya üzeri engeli olanlar ve 4'ten fazla çocuğu olanlar) sağlayan kişilere Avrupa Birliği tarafından Kızılay aracılığıyla Sosyal Uyum Yardımı (SUY) adı altında 120 tl nakit para yardımı yapılmaktadır (Multeciler Derneği, 2020). Avrupa ülkelerinin ise mültecilere farklı tutarlarda para yardımı yaptığı bilinmektedir. Bu tutarlar Almanya'da 354 euro, İtalya 75, İsveç 70 
+ çocuk başına 55 euro, Fransa'da ise 4 kişilik aileye 408 euro tutarında nakit para yardımı yapılmaktadır (Mültecilere hangi ülke. 2020).

Araştırma sonucunda elde edilen bulgulara göre mültecilerin toplumdan beklentileri, kendilerine sayg1 duyulması ve horlanmama, kötü gözle bakılmama ve iyi komşuluk ilişkileri kurmadır. Bu beklentiler birey ve insan olarak herkesin hakkıdır. İlgili alan yazına bakıldığında mültecilerin toplumsal kabul oranının çok düşük olduğu (\%21), özellikle sınır bölgelerinde yaşayanların, mültecilerin sosyal hayata katılmalarını istemedikleri, onlara çalışma izni verilmemesi gerektiğini, mültecilerin güvenlik sorunu yarattığını ifade ettikleri görülmektedir. Türklerin yaklaşık \% 45'inin yabancı komşu istemediği verisi (Turksam, 2019) mültecilerin toplumdan saygı, sevgi, komşuluk ve hor görülmeme beklentileri bulgusunu doğrulamaktadır. Ullah, Hasan, Mohamad ve Chattoraj (2020), 2018 ve 2019 arasinda Singapur, Malezya, Tayland, Endonezya ve Filipinler'de göç rejiminden politika yapıcılar ve uzmanlarla yaptıkları görüşmelerin sonucunda elde ettikleri bulguları payşaltıkları çalışmalarında; bu ülkelerde, göç ve güvenlik arasında aldatıcı bir ilişki oluşturulduğunu, bunun da azınlık gruplara ve mültecilere karşı aşırı önyargı oluşmasına yol açtığını belirtmişlerdir. Mültecilere yönelik güvenlik odaklı söylem ve yaklaşımların yerel topluluklarla mülteciler arasındaki gerilimi daha da artırdığını vurgulamışlardır.

Sonuç olarak; mültecilerin eğitime erişmeleri sürecinde yaşadıkları sorunlar ve sosyal içerilme beklentilerinin araştırıldığı bu çalışmada;

Mültecilerin eğitime erişim sürecinde dil, kültür, dışlanma-hor görülme ve şiddete uğrama gibi olumsuz durumlarla karşılaş̧ıkları görülmüştür. $\mathrm{Bu}$ durum önlem alınması gerektiğini göstermektedir. Eğitim hakkı, hem Türk Anayasasında hem de Uluslararası sözleşmelerle güvence altına alınmıştır. Bununla beraber katılımcıların öğretmenlerden memnuniyetinin yüksek olduğu olumlu bir veri olarak bulgulanmıştır.

Mültecilerin sosyal içerilme beklentileri ise iki başlık altında toplanmıştır. İlki, mültecilerin devletten beklentilerini kapsamaktadır. Bu beklentiler; vatandaşlık, sigortalı ve güvenceli çalışma, sağlık ve eğitime ücretsiz erişim ve kendilerine para yardımı yapılmasıdır. İkincisi ise, mültecilerin toplumdan beklentilerini kapsamaktadır. Bu kapsamda ise mülteciler, kendilerine saygı duyulması, iyi komşuluk ilişkileri geliştirilmesi ve hor görülmemelerini talep etmişlerdir. Sosyal içerme, bireylerin yaşadıkları ülkelerde ve toplumlarda, değerlerinin tanınması, insani gelişimlerinin desteklenmesi, karar mekanizmalarına katılımlarının sağlanması, ekonomik ve sosyal hayata dahil edilmeleri gibi boyutları olan bir kavramdır. Mültecilerin beklentileri bu boyutların karşılanmasıyla gerçekleşirse sosyal içermeden bahsedilebilir. Aksi takdirde sosyal dışlanma söz konusu olacaktır. Türkiye'nin mültecilerin toplumsal yaşama katılımlarının sağlanması ve sosyal olarak içerilmeleri, aynı zamanda toplumsal bütünleşmenin sağlanmasına yönelik politikalar geliştirmesi gerekliliği bu çalışmada açığa çıkan önemli bir bulgudur.

Yukarıdaki veriler ışığında uygulayıcılara yönelik olarak önerilerimiz;

a) Mültecilerin bazıları Kızılay kart aracıllğıyla verilen sosyal uyum yardımları ile geçimlerini sağlamaktadırlar. Bu kişilerin eğitim ve sağlık giderlerinin tamamı devlet tarafından karşılanmalıdır (Katkı payları alınmamalıdır). b) Devletin merkez organları, yerel yönetimler, okul idareleri ve muhtarlıklar ortaklaşarak etnik ayrımcılığı ortadan kaldıracak etkinlikler planlamalıdır. c) Ayrımcı davranış ve söylemde bulunan eğitimciler mutlaka uyarılmalıdır. Mültecilerin devam edebileceği okullarda kontenjan düzenlemesi bulunmalı, bazı okullardaki yığılmanın önüne geçilmelidir.

Araştırmacılara yönelik önerilerimiz ise;

a) Türkiye Cumhuriyeti vatandaşı olan ailelerin mültecilerin sosyal içerilmelerine yönelik görüşleri araştırılabilir. b) Diğer ülkelerdeki sosyal içerme faaliyetleri incelenerek kıyaslama 
yapılabilir. c) Sosyal içerme ile ilgili üniversite ögrencileri ve akademisyenler düzeyinde çalışmalar yapilabilir.

\section{Kaynakça}

Akkaya, A. (2013). Suriyeli mültecilerin Türkçe algıları. Ekev Akademi Dergisi. 17(56), 179-190.

Akpınar, T. (2017). Türkiye'deki Suriyeli mülteci çocukların ve kadınların sosyal politika bağlamında yaşadıkları sorunlar. Balkan ve Yakın Doğu Sosyal Bilimler Dergisi, 3(3), 1629.

Alpman, S. (2018). Göçmen kimliği ve emeği, sığınmacı kimliği ve iş gücü piyasası. Toplum ve hekim dergisi. 33(5), 337-347.

Arer, U. Y. (2020). Sürdürülebilir sosyal sorumluluk projesi olarak dezavantajlı grupların entegre yaşam alanlarının planlanması. ulakbilge, 44, s. 33-45.

Atkinson, R. (2004). The evidence on the impact of gentrifi cation: New lessons for the urban renaissance? European Journal of Housing Policy, 4(1), 107-131.

Aygül, H. H. (2018). Mülteci emeğinin Türkiye işgücü piyasalarındaki görünümü ve etkileri. Süleyman Demirel Üniversitesi Vizyoner Dergisi, 9(20), 68-82.

Béland, D. (2007). The social exclusion discourse: Ideas and policy change. Policy and Politics, $35(1), 123-139$.

Beltekin, N. (2016). Turkey's progress toward meeting refugee education needs the example of Syrian refugees. Eurasian Journal of Educational Research, 16(66), 175-190.

Biasutti, M., Concina, E., ve Frate, S. (2019). Working in the classroom with migrant and refugee students: the practices and needs of Italian primary and middle school teachers. Pedagogy, Culture \& Society, 1-17.

Bolgün, A. B. ve Uçan, G. (2020). Birlikte yaşamak mümkün mü?: Okur yorumlarında "Suriyeli sığınmacı” söyleminin inşası. Celal Bayar Üniversitesi Sosyal Bilimler Dergisi. 18(1), 250269.

Bozbeyoğlu, E. (2015). Mülteciler ve insan hakları. Hacettepe Üniversitesi Illetişim Fakültesi Kültürel Çalışmalar Dergisi, 2(1), 60-80.

Bullock, S., Brestovansky, M. ve Lenčo, P. (2015). Gençlik Çalışmalarında Sosyal İçerme, Çeşitlilik ve Eşitlik. İlkeler ve Yaklaşımlar. University of Gloucestershire Francis Close Hall campus. https://rideproject.eu/media/ride-the-principles-approaches-tr.pdf

Carpio, X. V. D. ve Wagner, M. (2015). The Impact of Syrian Refugees on the Turkish Labor Market, Policy Research Working Paper, World Bank Social Protection and Labor Global Practice Group. https://data2.unhcr.org/en/documents/download/54522.

Castillo, Y.D (1994). A comparative approachto social exclusion; Lessons from France and Belgium. International Labour Review, 133, pp. 613-633.

Collins, H. (2003). Discrimination, Equality and Social Inclusion. The Modern Law Review Limited, $66(1), 16-43$

Creswell, J. W. (2013). Nitel araştırma yöntemleri: Beş yaklaşıma göre nitel araştırma ve araştırma deseni. (M. Bütün ve S. B. Demir, Çev.). Siyasal Kitabevi. 
Das, M. B. (2016). Social inclusion in macro-level diagnostics: reflecting on the World Bank group's early systematic country diagnostics. Policy Research Working Paper. No. 7713.

Demir, O. Ö. (2014). Sosyal bilimlerde araştırma yöntemleri. Böke, K. (Ed). Alfa Basım Yayım.

Deniz, T. (2014). Uluslararası göç sorunu perspektifinde Türkiye. Türkiye Sosyal Araştırmalar Dergisi, (181), 175-204.

Deniz, A, Ç., Hülür, A, B. ve Ekinci, Y.(2016). Göç, strateji ve taktik: Suriyeli sığınmacıların gündelik hayat deneyimleri. Uluslararası Sosyal Araştırmalar Dergisi, 9(42), 1077-1087.

Doğanay, F. (1996). Türkiye'ye göçmen olarak gelenlerin yerleşimi. Erişim adresi: http://www.balgoc.org.tr/ gocmenyerlesim.html.

Donnelly, P. ve Coakley, J. (2002). The role of recreation in promoting social Inclusion. ISBN 09730740-8-6.https://laidlawfdn.org/wp-content/uploads/2014/08/wpsosi2002 decembertherole-of-recreation.pdf.

Erdem, C. (2017). Sınıfında mülteci öğrenci bulunan sınıf öğretmenlerinin yaşadıkları öğretimsel sorunlar ve çözüme dair önerileri. Medeniyet Eğitim Araştırmaları Dergisi, 1(1), $26-42$.

Erdoğan, M. M. (2015). Türkiye'deki Suriyeliler: Toplumsal kabul ve uyum. Hacettepe Üniversitesi Göç ve Siyaset Araştırmaları Merkezi Yayınları.

Erdoğan, M. (2017). Suriyeliler barometresi: Suriyelilerle uyum içinde yaşamın çerçevesi. İstanbul Bilgi Üniversitesi Yayınları.

Erdoğdu, S. (2004). Sosyal politikada “Avrupalı” bir kavram: sosyal dışlanma. Çalışma Ortamı Dergisi, (75), 16-19.

Ersoy, A. F. (2017). "Fenomenoloji”. Saban, A. Ve Ersoy, A. (Ed.). Eğitimde Nitel Araştırma desenleri içinde.(2.bs). Anı Yayıncılık.

Fernandez, R. M. (2020). Migrants and discrimination in the UK. The migration observatory. At the university of Oxford. https://migrationobservatory.ox.ac.uk/wp- content/uploads/2020/01/ Briefing-Migrants-and-Discrimination-in-the-UK.pdf

Genç, Y. ve Çat, Y. (2013). Engellilerin istihdamı ve sosyal İçerme İlişkisi. Akademik İncelemeler Dergisi, 8(1), 363-393.

Giovetti, O. (2019). Forced migration: 6 causes and examples. https://www.concernusa.org/story/ forced-migration-causes/

Göç İdaresi. (2020). Kitlesel akınlar. https://www.goc.gov.tr/kitlesel-akinlar. e.t: 12.03.2020.

Groenewald, T. (2004). A phenomenological research design illustrated. International Journal of Qualitative Methods, 3(1), 42-55.

Güler, M. A, (2014). Sosyal dışlanma bağlamında yeni toplumsal hareketler; Arap baharl, İspanya ve ABD örnekleri. (Yüksek Lisans Tezi). Gazi Üniversitesi.

Gültaç, A. S. ve Balçı, P. Y. (2018). Türkiye'de Suriyeli sığınmacılara yönelik sağlık politikaları. Sakarya Tip Dergisi. 8(2),193-204.

Gün, M. ve Baldık, Y. (2017). Türkiye'de kamp dışında misafir edilen Suriyeli sığınmacı gençlere yönelik eğitim hizmetleri (Kayseri Örneği), Rota Eğitim ve Sosyal Bilimler Dergisi, 4(2), 286-299.

Güner, N. Ö. (2016). Avrupa İnsan Hakları Mahkemesi’nin mültecilerin haklarının korunmasındaki rolü. Göç araştırmaları dergisi. 2(2), 212-241. 
Hayat Boyu Öğrenme Genel Müdürlüğ̈̈, (2019). https://hbogm.meb.gov.tr/meb.iys dosyalar/2019_03/06145652_04-Mart2019 internetsunu.pdf

Howard, R. T. (2017). "Migration Will Drive the Next Wave of World Wars." https://nationalinterest.org/feature/migration-will-drive-the-next-wave-world-wars-23737

Irmak, C., Bilginer, R. ve Çetin, T. (2018). Iraklı Türkmen Öğrencilerin göç kavramına yönelik düşünceleri. Anadolu Kültürel Araştırmalar Dergisi, 2(3), 87-101.

Kardeş, S. ve Akman, B. (2018). Suriyeli mültecilerin eğitimine yönelik öğretmen görüşleri. Illkögrretim online, 17(3), 1224-1237.

Khan, S., Combaz, E. ve McAslan Fraser, E. (2015). Social exclusion: topic guide. Revised edition. Birmingham, UK: GSDRC, University of Birmingham.

Klasen, S. (1999). Social exclusion, children, and education: conceptual and measurement issues. http://www.oecd.org/education/innovation-education/1855901.pdf. Son erişim:17.03.2020.

Kocadal, F., Tekin, N. E., Gökşin, S. ve Erbaş, U. S. (2019). Göçmenlere uygulanan sağlık politikaları. Konak sağllk ve sosyal bilimler dergisi, (2). https://konakdergisi.hayatvakfi.org.tr/. Son erişim: 18.03.2020.

Köse, N., Bülbül, Ö. ve Uluman, M. (2019). Sınıf öğretmenlerinin mülteci öğrencilere yönelik tutumlarının çeşitli değişkenler açısından incelenmesi. Journal of Continuous Vocational Education and Training, 2(1), 16-29

Kummitha, R. K. R. (2015). Social Exclusion: The european concept for Indian social reality. Social Change. 45(1), 1-23.

Kutlu, M. (2019). Türkiye'deki Suriyeli Mültecilerin Türkiye'nin iş gücü piyasasına ve istihdama etkileri üzerine bir değerlendirme. (Derleme makalesi). Dicle Üniversitesi İktisadi ve İdari Bilimler Fakültesi Dergisi, 9 (17), 45-59.

Lester, S. (1999). An introduction to phenomenological research. Stan Lester Developments, Taunton. http://www.sld.demon.co.uk/resmethy.pdf.

MEM. (2020). Samsun Milli Eğitim Müdürlüğü.

Miles, M. B. ve Huberman, A. M. (2015). Nitel veri analizi. (Sadegül Akbaba Altun \& Ali Ersoy, Çev. Ed.). Pegem.

Moralı, G. (2018). Suriyeli mülteci çocuklara Türkçenin yabancı dil olarak öğretiminde karşılaşılan sorunlar. Uluslararası toplum araştırmaları dergisi. 8(15), 1426-1451.

Morrison, Z. (2003). Recognising "recognition": Social justice and the place of the cultural in social exclusion policy and practice. Environment and Planning A, 35(9), 1629-1649.

Mülteci-Der, (2017). "Entegrasyon ve Sınır Politikaları Çerçevesinde Mültecilerin İçselleştirilmesi ve/ya Dışsallaştırılmasıı" Toplantı Notları. http://www.multeci.org.tr/yayinlar/

Mülteciler Derneği. (2020). Suriyeliler devletten para alıyor mu? https://multeciler.org.tr/suriyelilerdevletten-para-aliyor-mu/. Son erişim: 17.03. 2020.

Omidvar, R. ve Richmond, T. (2003). Immigrant settlement and social inclusion in Canada. (Working paper series Perspectives on social inclusion). Includes bibliographical references.https://maytree.com/wp-content/uploads/SummaryImmigrantSettlement AndSocialInclusion 2003.pdf.

ORSAM, (2015). Suriyeli Slğınmacıların Türkiye’ye Etkileri, Rapor No: 195. Ortadoğu Stratejik Araştırmalar Merkezi. 
Özdemir, M. (2010). Nitel veri analizi: Sosyal bilimlerde yöntembilim sorunsalı üzerine bir çalışma. Eskişehir Osmangazi Üniversitesi Sosyal Bilimler Dergisi, 11(1), 323-343.

Patton, M, Q. (2014). Nitel Araştırma ve Değerlendirme Yöntemleri. 3. Baskıdan çeviri. (Editörler Bütün, M. ve Demir, B Ş). Pegem.

PİKTES. (2020). PICTES nedir? (Suriyeli Çocukların Türk Eğitim sistemine Entegrasyonunun Desteklenmesi Projesi). https://piktes.gov.tr. Son erişim: 15.03.2020

Raabe, I.J. (2018). Social exclusion and school achievement: Children of immigrants and children of natives in three European countries. Child Ind Res, 12, 1003-1022.

Türkiye'ye İltica Eden veya Başka Bir Ülkeye İltica Etmek Üzere Türkiye'den İkamet İzni Talep Eden Münferit Yabancılar ile ilgili yönetmelik Yönetmelik (1994, 30 Kasım). Resmi Gazete (Say1:22127). Erişim adresi: https://www.resmigazete.gov.tr/arsiv/22127.pdf.

Sağlam, H. İ. ve Kanbur, N. İ. (2017). Sınıf öğretmenlerinin mülteci öğrencilere yönelik tutumlarının çeşitli değişkenler açısından incelenmesi. Sakarya University Journal of Education, 7(2), 310-323.

Sakız, H. (2016). Göçmen çocuklar ve okul kültürleri: Bir bütünleştirme önerisi. Göç Dergisi (GD), $3(1), 65-81$.

Saklan, E. (2018). Türkiye'deki Suriyeli eğitim çağı çocuklarının eğitim süreçleri üzerine bir çözümleme. (Yayımlanmamış doktora tezi). Ankara Üniversitesi.

Sapancalı, F. (2005). Sosyal Dışlanma, Dokuz Eylül Yayınları.

Shortall, S. (2003). Phenomenology. A to Z of social research. edited by Robert L. Miller and John D. Brewer. SAGE Publications Ltd 6 Bonhill Street. London EC2A 4PU.

Şahin, M. ve Doğan, Y. (2018). Suriyeli öğrencilerin bulunduğu sınıflarda fen bilimleri öğretiminde karşılaşılan sorunlar: Nitel bir çalışma. Uluslararası Eğitim Araştırmacıları Dergisi, 1(1), 13-33.

Şahin, T. (2009). Sosyal Dışlanma ve Yoksulluk İlişkisi. Başbakanlık sosyal yardımlaşma ve dayanışma genel müdürlügü. Sosyal Yardım Uzmanlık Tezi.

Şahin, H. (2020). Göç olgusu, mülteci çocukların eğitimi ve Suriyeli mülteci çocukların Türk eğitim sistemine entegrasyonu süreci. Uluslararası Türkçe Edebiyat Kültür Eğitim Dergisi, 9(1), 377-394.

Şimşir, D. ve Dilmaç, B. (2018). Yabanc1 uyruklu öğrencilerin eğitim gördüğü okullarda öğretmenlerin karşılaştığı sorunlar ve çözüm önerileri. İlköğretim Online, 17(3), 1719-1737.

Silver, H. (1994). Social exclusion \& social solidarity: Three paradigms. International Labour Review, (133), 531-578.

Stalker, P. (2002). Migration trends and migration policy in Europe, International Migration, 40(5), 151-179.

Sümbüloğlu, I., Karabey, S., Gülle, B., Saillard, E., ve Koca, E. (2019, September). Suriyeli çocukların okul ortamında sosyal içerilmesine iliş̧kin geliş̧tirilmiş psikososyal destek programi: YanYana Projesi. In 3. International 21. National Public Health Congress.

Tania, B., Julian, L. G. ve David P. (1999). Social exclusion in Britain 1991-1995. Social Policy \& Administration, 33(3), 227-244. 
Topçu, Z., Türk, M. S. ve Kantos, Z. E. (2018). Türkiye'de bulunan mültecilerin karşılaştıkları sorunlar ile ilgili nitel bir çalışma. Uluslararası Medeniyet Çalışmaları Dergisi, 3(2), 191 205.

Turksam, (2019). Göç Bülteni. http://turksam.org/turk sam-goc-gocmen-bulteni-30-ocak-2019

Tufan, T. (2001). Irakta Türkmen azınlık ve Kerküklü göçmenler. (Yayımlanmamış yüksek lisans tezi). Marmara Üniversitesi.

Tunga Y., Engin G., ve Çağıltay, K. (2020). Türkiye'deki Suriyeli çocukların eğitiminde karşılaşılan sorunlar üzerine bir alanyazın taraması. İnönü Üniversitesi Eğitim Fakültesi Dergisi, 21(1), 317-333.

Türk, E. (2020) Suriyeli göçmenlerin Türk vatandaşlığı hakkındaki görüş ve beklentileri. Selçuk Üniversitesi Sosyal Bilimler Enstitüsü Dergisi, (43), 162-176.

Ullah, A. A., Hasan, H. N., Mohamad, M. S. ve Chattoraj, D. (2020). Migration and security: Implications for minority migrant groups. India Quarterly, s. 1-18. DOI:10.1177/0974928419901199 journals.sagepub.com/home/iqq

UNCHR. (2019). Unchr Türkiye İstatistikleri. https://www.unhcr.org/tr/unhcr-turkiye-istatistikleri

UNESCO. (1994). World Conference on Special Needs Education: Access and Quality, Salamanca, Spain, 1994. https://unesdoc.unesco.org/search/N-EXPLORE-b2ce1021-de7e-433f-b7c51afa5b5b4c55. Son erişim: 18.03.2020

UNESCO. (2019). Küresel eğitim ve izleme raporu. https://unesdoc.unesco. org/ark: /48223/ pf0000265996_tur

UNICEF. (2019). Türkiye'de Suriyeli Çocuklar. https://www.unicefturk.org/yazi/acil-durumturkiyedeki-suriyeli-cocuklar

United Nations. (2013). A new global partnership: eradicate poverty and transform economies through sustainable development. Report of the high-level panel of eminent persons on the post-2015 development agenda, New York. http://www.post2015hlp.org/wpcontent/uploads/2013/05/UN-Report.pdf.

Uzun, A. (2015). Günümüzün sosyal ve ekonomik sorunu olan Suriyelilerin mülteci ve ekonomi hukuku bakımından değerlendirilmesi. Ankara Barosu Dergisi, 73(1), 105-120.

Yavuz, Ö. ve Mızrak, S. (2016). Acil durumlarda okul çağındaki çocukların eğitimi: Türkiye'deki Suriyeli mülteciler örneği. Göç Dergisi, 3(2), 175-199.

Yıldırım, A. ve Şimşek, H. (2013). Sosyal bilimlerde nitel araştırma yöntemleri (9. bs). Seçkin.

Yıldırım, A. (1999). Nitel araştırma yöntemlerinin temel özellikleri ve eğitim araştırmalarındaki yeri ve önemi. Eğitim ve Bilim Dergisi, 23(112), 7-17. 